\title{
Deep structure of the continental margin and basin off Greater Kabylia, Algeria - New insights from wide-angle seismic data modeling and multichannel seismic interpretation
}

\author{
Aidi Chafik ${ }^{1,}{ }^{*}$, Beslier Marie-Odile ${ }^{2}$, Yelles-Chaouche Abdel Karim ${ }^{1}$, Klingelhoefer Frauke ${ }^{3}$, \\ Bracene Rabah ${ }^{4}$, Galve Audrey ${ }^{2}$, Bounif Abdallah ${ }^{5}$, Schenini Laure ${ }^{2}$, Hamai Lamine ${ }^{1}$, \\ Schnurle Philippe ${ }^{3}$, Djellit Hamou ${ }^{1}$, Sage Françoise ${ }^{2}$, Charvis Philippe ${ }^{2}$, Déverchère Jacques ${ }^{6}$
}

${ }^{1}$ Centre de Recherche en Astronomie Astrophysique et Géophysique (CRAAG), Algiers, Algeria

${ }^{2}$ Université Côte d'Azur, CNRS, Observatoire de la Côte d'Azur, IRD, Géoazur, Nice Sophia-Antipolis, France

${ }^{3}$ Institut Français de la Recherche pour l'Exploitation de la Mer (IFREMER), Plouzané, France

${ }^{4}$ Sonatrach, DXP Boumerdès, Algeria

${ }^{5}$ Université des Sciences et de la Technologie Houari Boumediène, Algiers, Algeria

${ }^{6}$ Géosciences Océan, UBO-CNRS (UMR6538), IUEM, Plouzané, France

* Corresponding author : Chafik Aidi, email address : $\underline{\text { c.aidi@craag.dz }}$

\begin{abstract}
:
During the Algerian-French SPIRAL survey aimed at investigating the deep structure of the Algerian margin and basin, two coincident wide-angle and reflection seismic profiles were acquired in central Algeria, offshore Greater Kabylia, together with gravimetric, bathymetric and magnetic data. This $\sim 260 \mathrm{~km}$-long offshore-onshore profile spans the Balearic basin, the central Algerian margin and the Greater Kabylia block up to the southward limit of the internal zones onshore. Results are obtained from modeling and interpretation of the combined data sets.
\end{abstract}

The Algerian basin offshore Greater Kabylia is floored by a thin oceanic crust $(\sim 4 \mathrm{~km})$ with P-wave velocities ranging between 5.2 and $6.8 \mathrm{~km} / \mathrm{s}$. In the northern Hannibal High region, the atypical 3-layer crustal structure is interpreted as volcanic products stacked over a thin crust similar to that bordering the margin and related to Miocene post-accretion volcanism. These results support a two-step back-arc opening of the west-Algerian basin, comprising oceanic crust accretion during the first southward stage, and a magmatic and probably tectonic reworking of this young oceanic basement during the second, westward, opening phase. The structure of the central Algerian margin is that of a narrow $(\sim 70 \mathrm{~km})$, magma-poor rifted margin, with a wider zone of distal thinned continental crust than on the other margin segments. There is no evidence for mantle exhumation in the sharp ocean-continent transition, but transcurrent movements during the second opening phase may have changed its initial geometry. The Plio-Quaternary inversion of the margin related to ongoing convergence between Africa and Eurasia is expressed by a blind thrust system under the margin rising toward the surface at the slope toe, and by an isostatic disequilibrium resulting from opposite flexures of two plates decoupled at the continental 
slope. This disequilibrium is likely responsible for the peculiar asymmetrical shape of the crustal neck that may thus be a characteristic feature of inverted rifted margins.

\section{Highlights}

- Modeling of deep seismic data images the deep structure of the Algerian margin. The Algerian margin offshore Greater Kabylia is a narrow, magma-poor rifted margin. Margin inversion may trigger lower crust seaward flow due to isostatic disequilibrium. A 3-layer thin oceanic crust reveals postaccretion volcanism in the Algerian basin. A two-step Miocene evolution of the West Algerian backarc basin is proposed.

Keywords : Mediterranean Sea, Algerian margin, Crustal structure, Tectonic inversion, Post-accretion magmatism, Deep seismics 


\section{Introduction}

The Algerian margin, located in the western Mediterranean basin, is a well-suited and rare example of a rifted margin where to address fundamental questions regarding the processes of tectonic inversion. The Algerian basin resulted from back-arc extension behind the rollback of a northward directed subduction during Oligocene and Miocene (Réhault et al., 1985). Continental breakup and accretion of new oceanic seafloor occurred between the Balearic Islands and the Kabylia blocks (Bouillin et al., 1986). This phase of opening ended after the subduction had completely consumed the Tethys Mesozoic lithosphere with the 
collision of the relatively buoyant continental Kabylia blocks onto the African margin (e.g., Frizon de Lamotte et al., 2000). After the Messinian salinity crisis that resulted in thick evaporitic deposition in the basin and erosion on the margin, the ongoing convergence of the African and European plates subsequently led to the inversion of the margin during the Plio-Quaternary (e.g. Auzende et al., 1973; Réhault et al., 1984; Frizon de Lamotte et al., 2000; Mauffret et al., 2007). The Algerian margin undergoes today a moderate to high seismicity, as exemplified by the reverse Mw 6.9, 2003 Boumerdes earthquake (Delouis et al., 2004). While the opening history of most neighbouring basins (e.g. the LiguroProvencal basin) is generally well understood today (Gueguen et al., 1998; Jolivet and Faccenna, 2000; Rosenbaum et al., 2002), the geodynamic evolution of the Algerian margin and basin is still a matter of discussion. Some of the remaining questions concern the direction of opening and the nature of the oceanic basement, the deep crustal structure of the steep and narrow margin and the expression of its tectonic inversion.

The central part of the Algerian margin (Greater Kabylia region) represents the transition between the very steep western part that is assumed to be a STEP (Subduction Transform Edge Propagator, Govers and Wortel, 2005) margin shaped behind the rollback of the Gibraltar subduction zone (Badji et al., 2015), and the more progressively thinned eastern part (Bouyahiaoui et al., 2015). This is a region of high seismic activity depicting a dominant compressional stress field (Yelles et al., 2006; Serpelloni et al., 2007). This high seismic activity is related to Plio-Quaternary inversion of the margin, and is expressed as south-dipping blind thrusts under the margin emerging at the slope toe (Déverchère et al., 2005; Domzig, 2006; Yelles et al., 2009; Strzerzynski et al., 2010) and a large-scale downward flexure of the oceanic plate, which could indicate a southward dipping nascent subduction (Hamai et al., 2015). This region is characterised onland by the presence of the Greater Kabylia block accreted onto the African continental margin. 
Nord de l'Algérie) has been performed in order to investigate the deep structure of the Algerian margin. During the SPIRAL survey conducted in October-November 2009 onboard R/V L'Atalante, combined wide-angle (WAS) and multichannel reflection seismic (MCS) data were acquired along five main north-south transects sampling the complete margin, together with complementary MCS, gravity and magnetic profiles. In this paper, results from modeling the land-sea profile crossing the central Algerian margin in the Greater Kabylia region are presented together with results from the interpretation of the coincident reflection seismic data. This paper aims at exploring the nature and large-scale structure of the continental margin, with particular attention to the expression of the inversion linked to the compressional setting between African and European plates, the nature and structure of the crust adjacent to the margin and of the ocean-continent transition, and the nature and structure of the Hannibal High in the oceanic domain.

\section{Geological setting}

\subsection{Geodynamic framework}

The Algerian basin is located between the Eastern Alboran basin to the west, the Sardinian and Tunisian margins to the east and the Balearic margin to the north (Figure 1A). Its present-day configuration results from the subduction of the Tethyan Ocean underneath the European plate in mid-Cenozoic times (e.g. Auzende et al., 1973; Réhault et al., 1984; Frizon de Lamotte et al., 2000). The Algerian margin was formed in the frame of back-arc opening of the Western Mediterranean basins in late Oligocene to early Miocene owing to the rollback of the Tethyan slab (Carminati et al., 1998a, b; Gueguen et al., 1998; Jolivet and Faccenna, 2000; Gelabert et al., 2002; Rosenbaum et al., 2002; Faccenna et al., 2004) (Figure 1). This subsequently caused the drift of the European forearc, namely the AlKaPeCa domain (for Alboran, Kabylia, Peloritani, Calabria; Bouillin et al., 1986), towards the south, SE and SW. Originally located along the European margin, the forearc 
broke into several blocks whose migration ended with the collision with the Tethyan margin to form the internal zone of the Alpine Peri-Mediterranean chains (e.g. Bouillin et al., 1986; Vergés and Sàbat, 1999; Frizon de Lamotte et al., 2000; van Hinsbergen et al., 2014). A double arcuate subduction system developed toward the west (Alboran) and the east (Calabria) (Lonergan and White, 1997; Carminati et al., 1998a, b; Gelabert et al., 2002; Rosenbaum et al., 2002; Rosenbaum and Lister, 2004; Spakman and Wortel, 2004). The geodynamic evolution of the western Mediterranean basin is widely debated, especially concerning the opening age and direction of the Algerian basin as the poorly organized magnetic pattern in the western Mediterranean does not allow age modeling and clear opening trend identification (Schettino and Turco, 2006 and references therein). However most geodynamic models accepted today postulate the existence of two sub-basins in the Algerian basin with different opening trends and evolutions.

In the west Algerian basin (WAB; Figure 1), a two-step evolution is proposed (insets in Figure 1), including a south to south-eastward drift of the AlKaPeCa block leading to the collision of the Kabylian block with the African plate ( 17 Ma) (Abbassene et al., 2016) and the subsequent detachment of the slab (e.g. Maury et al., 2000; van Hinsbergen et al., 2014; Abbassene et al., 2016). Recent tomographic studies depict a northward dipping detached slab between $\sim 250$ and $\sim 660 \mathrm{~km}$ beneath the Algerian basin, which is segmented and slightly shifted, in its upper part, beneath the study area (Fichtner and Villaseñor, 2015). A second step followed between 16 and $8 \mathrm{Ma}$ with the E-W opening and oceanic crust formation in the actual WAB (Mauffret et al., 2004; Booth-Rea et al., 2007). Recent exploration of the western Algerian margin and continent-ocean boundary, including the SPIRAL project, indicates that the westward migration of the Alboran block following the slab retreat probably resulted in the formation of a 'STEP' boundary along the western Algerian margin (Vergés and Fernàndez, 2012; Medaouri et al., 2014; Badji et al., 2015). Crustal accretion would have occurred along a N-S trending fossile accretionary centre, the 
Hannibal Ridge (Mauffret et al., 2004). The Hannibal Ridge is a cluster of basement highs correlated to a sub-circular group of high amplitude magnetic anomalies (Schettino and Turco, 2006) located about $120 \mathrm{~km}$ northward of the coastline in the central part of the Algerian basin. The location of the Hannibal Ridge in the eastern part of the basin then implies an asymmetric spreading with accretion of $400 \mathrm{~km}$ oceanic crust toward the west and only $160 \mathrm{~km}$ toward the east (Mauffret et al., 2004). Its activity is assumed to have ceased at $8 \mathrm{Ma}$ when the Tyrrhenian basin began to open.

Tomographic studies conducted in the Eastern Mediterranean spanning the Tyrrhenian basin and Calabria (Spakman and Wortel, 2004) suggest a mirror symmetric slab geometry accompanying an eastward slab rollback (Malinverno and Ryan, 1986; Rosenbaum and Lister, 2004). A one-step model of evolution of the eastern Algerian basin (EAB) before the Lesser Kabylian block collision is proposed from the eastern wide-angle seismic SPIRAL profile and the magnetic data offshore Annaba (Bouyahiaoui et al., 2015). Accordingly, the opening would be the surface expression of a slab tear at depth due to the increasing trenchlength of the subduction during its curvature.

The deep seismic profile presented in this study is located in the central part of the Algerian basin, close to the proposed limit between both rollback systems. The profile ends northward in the Hannibal High region (Figure 2).

\subsection{Onshore geology}

Northern Algeria is part of the Alpine belt that spans from Morocco to Calabria where it is called the Maghrebides (Durand Delga, 1969; Wildi, 1983). In central Algeria, it consists mainly of the Greater Kabylia block that was accreted to the paleo-African margin and extends in the offshore domain (Domzig et al., 2006).

The onshore domain along the Greater Kabylian meridian is divided into two sub-domains, the inner and outer zones. To the north, the inner zone called "Kabylide domain" 
represents part of the $\mathrm{AlKaPeCa}$ block that originally belonged to the northern margin of the Tethyan ocean. Its structure displays imbricate tectonic units made of Hercynian or older metamorphic rocks, granitoids, and Paleozoic sediments (Durand Delga and Fontboté, 1980; Wildi, 1983; Bossière and Peucat, 1985; Saadallah and Caby, 1996). It includes some highgrade metamorphic and ophiolitic rocks similar to those described at Cape Bougaroun in Lesser Kabylia (e.g., Bouillin and Kornprobst, 1974; Saadallah and Caby, 1996; Caby et al., 2001; Abbassene et al., 2016, and references therein). This basement is unconformably overlain by (1) the clastic marine deposits of the Kabylian Oligo-Miocene (OMK of Upper Oligocene, Aquitanian and Burdigalian age (Géry et al., 1981), (2) olistostrome-bearing flysch nappes emplaced in Burdigalian times (Bouillin et al., 1973; Bouillin, 1986), and (3) the discordant 1000-1500 m thick Miocene marine series of the Tizi Ouzou - Dellys basin (Figure 2) of Burdigalian to Serravalian age (Raymond, 1976; Belanteur et al., 1995; Aïte and Gélard, 1997). Miocene magmatism occurred in the Dellys area (Figure 2) and includes basaltic and andesitic lava flows dated between 15.6 and 11.8 Ma (Chazot et al., 2017 and references therein). The Mesozoic to Cenozoic cover of the Kabylian basement forms the Kabylian Ridge ("Dorsale Calcaire") that marks the southern thrusted limit of the internal domain (Durand Delga, 1969; Wildi, 1983; Bouillin, 1992). Further to the south, the outer (or Tellian) zone (Wildi, 1983) represents the southern margin of the Tethyan ocean before the Kabylian block collision (Bracene et al., 2003). It is composed of Mesozoic and Cenozoic allochthonous deposits forming a south- or southeast-verging Miocene pile of nappes that overthrust the Atlas foreland (Wildi, 1983; Bracene et al., 2003)(Figure 1B). The sedimentary cover of the closed Tethys oceanic domain occurs as complex flysch units of various ages that are either thrusted toward the south on the foreland or backthrusted toward the north on the internal zones up to the coastline (Bouillin et al., 1973).

\subsection{Offshore geology}

The offshore domain is located between the Balearic promontory to the north and the 
Algerian continental margin to the south (Figure 1). The sedimentary cover of the basin displays Miocene to Quaternary sedimentary series usually found in the western Mediterranean basins, including the Messinian evaporitic series often disturbed by salt diapirism (Sàbat et al., 1995; Mauffret et al., 2007). The interpretation is assessed by the DSDP site 371 borehole located $\sim 60 \mathrm{~km}$ eastward of the study area (location on Figure 1). Drilling sampled a thin subaerial Messinian evaporitic layer of nodular anhydrite under a $\sim 0.5 \mathrm{~km}$ thick, Quaternary to lower Pliocene, sequence of calcareous mudstones (Hsü et al., 1978). Beneath the Messinian evaporites, a 2-3 km thick pre-Messinian layer of Langhian to Tortonian age was sampled by several oil wells (Cope, 2003). Due to the lack of sampling of the basement and to the irregular magnetic pattern in the basin, the nature of the crust is debated. However, geophysical data in the northern half of the basin support a thin $(5-6 \mathrm{~km})$ oceanic-type crust (Hinz, 1973; Galdeano and Rossignol, 1977; Vidal et al., 1998; Pesquer et al., 2008; Grevemeyer et al., 2011) that is comparable to the thin oceanic crust $(\sim 5 \mathrm{~km})$ imaged in the neighbouring Liguro-Provençal basin (Pascal et al., 1993). In most of the basin, the Moho depth does not exceed $14 \mathrm{~km}$ (Hinz, 1973). Although the exact age of the Algerian basin is unknown, an age between $~ 21 \mathrm{Ma}$ and $16 \mathrm{Ma}$ has been proposed based on paleo-stress modeling constrained by geological and tomographic studies (Carminati et al., 1998a,b), and of 17-18 Ma from onland geological evidences and geochronological dating (Bruguier et al., 2009; Abbassene et al., 2016). Younger oceanic crust (12 to $8 \mathrm{Ma}$ ) has been identified in the westernmost part of the Algerian basin (Mauffret et al., 2004; Booth-Rea et al., 2007).

\subsection{Plio-Quaternary tectonic inversion}

Little is known about the syn-rift structure and evolution of the margin, but its PlioQuaternary evolution is controlled by the convergent geodynamical setting that induces a high to moderate seismic activity, compressional tectonics and vertical movements, both onshore and offshore. The recent (Mw 6.8, 2003) Boumerdes earthquake occurred $50 \mathrm{~km}$ 
westward of the study area, along a south-dipping thrust located at about $10 \mathrm{~km}$ under the coastline (Delouis et al., 2004). High resolution seismic and bathymetric data from the MARADJA cruise reveal Plio-Quaternary perched sub-basins at mid-continental slope and at the margin toe offshore Boumerdes and Dellys, which are formed in relation to faultrelated folds over south-dipping ramps (Domzig et al., 2006; Strzerzynski et al., 2010). The set of active structures is interpreted as a south-dipping blind thrust system under the margin emerging at the slope toe and related to the tectonic inversion of the margin (Déverchère et al., 2005; Domzig et al., 2006; Yelles et al., 2009; Strzerzynski et al., 2010). Although some lateral variation occurs in the geometry of these sub-basins, they are continuous offshore Greater Kabylia from Boumerdes to Bejaïa, suggesting that the related south-dipping ramp extends eastward in the study area offshore Tigzirt (Domzig, 2006). Comparable inversionrelated features are described off the Algerian margin from Tenes to Annaba (Domzig et al., 2006; Yelles et al., 2006, 2009; Kherroubi et al., 2009; Leprêtre et al., 2013; Badji et al., 2015; Bouyahiaoui et al., 2015). Onland, the tectonic inversion is expressed by ${\mathrm{N} 75^{\circ}}^{\circ}$ trending, $20 \mathrm{~km}$-wide, folds in the Miocene series in the Dellys and Tizi Ouzou area (Aïté and Gélard, 1997) whose asymmetry suggests that they are connected at depth to southdipping, blind thrust faults, and by an uplift of at least $900 \mathrm{~m}$ of the Miocene series since their deposition (Strzerzynski et al., 2010 and references therein). The inversion is also emphasized by a large-scale downward flexure of the oceanic plate and an isostatic overcompensation at the margin toe that might indicate possible southward dipping nascent subduction (Hamai et al., 2015). The crustal flexure is the largest off Greater Kabylia that is in the study area (Hamai et al., 2015).

\section{Data acquisition, quality and processing}

The wide-angle seismic data presented in this study were acquired during the SPIRAL cruise (October-November 2009) and are located in the Algerian basin off northern Kabylia 
(Figures 1A, 2). 40 Ocean Bottom Seismometers (OBS) from the Ifremer pool were deployed with a $\sim 3 \mathrm{~km}$ spacing along a $140 \mathrm{~km}$ long profile spanning from the Algerian continental margin into the oceanic basin. On land, the profile was extended by 24 seismological stations deployed at a $\sim 4 \mathrm{~km}$ interval along a $124 \mathrm{~km}$ long profile spanning the main geological units of northern Algeria, including the internal domain, the main thrust along the Kabylian Ridge and the adjacent Tellian domain (Figure 2).

For the wide-angle seismic experiment, the seismic sources were composed of a tuned airgun array of 10 air-guns providing a total volume of $1461\left(8909 \mathrm{in}^{3}\right)$ and generating 1031 low-frequency shots along the profile, synchronized on the first peak. The shot interval was set to $60 \mathrm{~s}$ leading to $\sim 150 \mathrm{~m}$ trace spacing. Preprocessing of the OBS data included calculation of the clock-drift corrections to adjust the clock in each instrument to the GPS base time, and instrument relocation using the direct water wave arrival to correct for drift from the deployment position during their descent to the seafloor. In order to increase the signal-to-noise ratio and to better image far-offset arrivals, a processing sequence including a spectral whitening deconvolution, a 3-17 Hz Butterworth filter and an automatic gain control was applied to all data (Figure 3). A good signal to noise ratio was obtained from all the OBS and from the 10 northern land stations, while no signal was recorded on the 14 southward stations located beyond the main thrust between the internal and external domains (Figure 2). Travel-time picking was done manually using the Seismic Unix software package (Stockwell, 1999) (Figure 3). For the forward modeling, picking uncertainties were defined for each phase according to the depth of the layer from which the phase originates. During inversion, picking errors of $70-125 \mathrm{~ms}$ were assigned respectively to near-offset and far-offset arrivals.

The MCS profile SPI11 coincident with the wide-angle profile presented in this study was acquired using an airgun array consisting of 13 airguns with a total volume of 501 $\left(3051 \mathrm{in}^{3}\right)$ synchronized on the first bubble to generate low frequency shots and to enhance 
deep penetration of the seismic signal (Avedik et al., 1993). A shot interval of $20 \mathrm{~s}$ resulted in a $\sim 50 \mathrm{~m}$ shot spacing. Quality control and preliminary stacking of the multichannel seismic data were performed with the SolidQC software of Ifremer. A complete processing sequence was then applied using the Geocluster processing package (CGG) including phase correction, spherical divergence correction, external mute, multiple attenuation, and timevariant band-pass filtering. NMO velocity analyses were performed every $200 \mathrm{CMP}$ (common midpoint, $1250 \mathrm{~m}$ ), in six successive iterations before stacking. The final section was obtained from a pre-stack Kirchhoff time-migration with a velocity model picked on 1250 m-spaced migrated CMPs.

Magnetic and gravity data were acquired simultaneously along the profile. Gravity data were acquired by a Lockheed Martin BGM-5 gravimeter, providing measurements every $10 \mathrm{~s}(\sim 25 \mathrm{~m})$. The data were tied to absolute gravity via a reference point located in Oran harbour and the instrument drift was linearly corrected between ties, before and after the cruise. Magnetic data were recorded at $60 \mathrm{~s}(\sim 150 \mathrm{~m})$ intervals with a $\sim 0.2 \mathrm{nT}$ accuracy using a SeaSpy magnetometer. The magnetic anomaly was computed using the IGRF 2005 model. Additional older magnetic data recorded between 1969 and 1974 by Aeroservice Corporation (Galdeano and Rossignol, 1977; Asfirane and Galdeano, 1995) were also used in this study to draw a magnetic map in which a reduced-to-the-pole filter (RTP) was applied to position the anomalies vertically of the magnetic sources. An upward continuation of $4 \mathrm{~km}$ was also performed in order to eliminate the high frequency noise and to keep the large wavelength anomalies representative of large geological structures.

\section{Seismic data modeling}

The wide-angle seismic data were modeled using a forward modeling approach that allows including results from reflection seismic interpretation. A minimum structure approach was 
used to avoid the inclusion of artefacts unconstrained by the data into the model. All layers included into the final model are constrained by reflective and turning wave arrivals. A topdown approach was applied and extensive error calculations were performed including resolution, ray density, depth and velocity perturbation and synthetic seismogram calculations to identify highly and less well constrained regions in the model. Finally seismic velocities were converted into densities to additionally check the velocity model by gravity modeling and identify regions in the model unconstrained by rays.

\subsection{Forward modeling of the wide-angle seismic data}

The data were modeled using the inversion and ray tracing algorithm "RAYINVR" (Zelt and Smith, 1992) (Figure 4) in order to include secondary arrivals and information from the multi-channel seismic data. Modeling was performed using a layer-stripping approach, proceeding from the top of the structure toward the bottom. Upper layers that were not directly constrained by arrivals from within the layer were adjusted to improve the fit of lower layers. Depth and velocities were modeled such as to minimize the difference between the observed arrival times and the arrival times computed in the model (Figure 5). Arrival times of the main sedimentary layers and basement were picked from the reflection seismic data. These were converted to depth using the OBS data, and included into the modeling at a lateral interval depending on the topography and depth. On land topography was included from altimeter measurements at each land-station. The depth and velocities of the crustal layers and the upper mantle were modeled from wide-angle data and confirmed by gravity modeling and synthetic seismogram calculations.

\section{2. Error analyses of the velocity model}

In order to assess the reliability of the velocity model different tests were conducted, including calculation of the model resolution, ray density, depth and velocity perturbations 
and synthetic seismograms.

The fit between predicted arrival times and travel-time picks allows to quantify the quality of the model. The final model resulting from forward modeling results in a travel-time misfit of $82 \mathrm{~ms}$ and explains $91 \%$ of the picks. The number of picks, RMS (root mean square) error, and chi-square error for each phase are listed in Table 1.

The ray density is calculated for the forward model on a grid of $0.5 \times 0.5 \mathrm{~km}$ cell size and is generally high in the middle parts of the model decreasing to the ends and within greater depth (Figure 6). The ray coverage is lower underneath the land stations due to the missing shots on land.

As second criteria to quantify the quality of forward modeling, resolution calculations were performed. Resolution is a measure of the number of rays passing through a region of the model constrained by a particular velocity node and is therefore dependent on the node spacing (Zelt, 1999). If a layer can be modeled using one single velocity gradient, then the resolution parameter will be high even in areas that have lower ray coverage, as the area is related to only one velocity node. Rays penetrating a layer on their trajectory to deeper layers are taken into account in the resolution parameter calculation. As compared to tomographic approaches where the resolution parameter shows the number of rays passing through one grid cell (analogue to the ray density plot of Figure 6), in forward modeling the resolution parameter is used to verify that the model is not over-parameterized, e.g. too many lateral velocity changes have been included. Nodes with values greater than 0.5 can be considered as well resolved (Zelt, 1999). The velocities throughout the model show a resolution higher than 0.5 except at the ends of the model and again in depth (Figure 7). The reason for the decrease at the ends of the model is a decreasing number of rays passing through each layer. Similarly the ray number and resolution decrease at the very shallow onshore sedimentary layer due to missing reverse shots on land. Upper-mantle velocities are 
well constrained at directly underneath the Moho, however less so at increasing depth due to fewer rays penetrating into this deeper portion of the model.

In order to estimate the velocity and depth uncertainties of the final velocity model, a perturbation analysis was performed analogous to previous studies in the study region (e.g. Leprêtre et al., 2013). The depths of the Moho interface and the velocity of the lower crustal layer were varied separately at first, and an $F$ test was applied to determine if a significant change between models could be detected. The $95 \%$ confidence limit gives an estimate of the depth uncertainty of the interface (Figures 8). In order to better constrain uncertainty at the Moho, both the depth of this interface and velocities in the lower crustal layer were changed systematically (Figure 8). Results from this analysis show that our preferred model from forward modeling allows a maximum of picks to be explained, with a minimum resulting misfit between the picked traveltimes and arrivals predicted from the modeling. Solutions leading to better fits explain a lower number of picks.

\subsection{Gravity modeling}

The velocities of the forward model were converted to density using an empirical law (Ludwig et al., 1970) and a density model was constructed. A constant density of $3.32 \mathrm{~g} / \mathrm{cm}^{3}$ was used for the mantle layer. This density model was then used to generate a predicted gravity anomaly that can be compared to the measured gravity anomaly and thereby confirm the velocity model. Additionally, areas unconstrained by the seismic data can be modeled using the gravity data. The gravity data were forward modeled using the "gravmod" module of the "RAYINVR" software (Zelt and Smith, 1992) and compared to the free-air gravity anomaly data collected during the SPIRAL cruise (Figure 9). For modeling purposes, the model was extended by $100 \mathrm{~km}$ at the ends and to a depth of $95 \mathrm{~km}$. The fit along the profile is generally very good, with the highest discrepancies at the model ends, where the seismic model is less well resolved. 


\section{Results}

In this part, the interpretation of the velocity model obtained from the wide-angle data and the coincident multichannel seismic data are used to reveal the large-scale structure of the margin and basin off Greater Kabylia.

\subsection{Main stratigraphic and structural features on SPI11 MCS profile}

The main features interpreted from the SPI11 profile, which is coincident with the wideangle profile, are presented in Figure 10 and synthesised below. The sedimentary cover, well characterised in the Mediterranean Sea and previously described in the WAB (e.g. Mauffret et al., 1987, 2004; Domzig et al., 2006), is well defined in the central part of the section (km 75 to 115). It includes from top to bottom: (1) the low-amplitude, highfrequency seismic facies of the Plio-Quaternary series (PQ), (2) the Messinian sequence, namely the highly reflective set of reflectors of the upper unit (UU), the mobile unit (MU) made of evaporites and forming locally domes and diapirs, underlined at its base by a strong and continuous reflector (BMU) at $\sim 4.5-4.8$ stwt (seconds two-way traveltime) depth, and (3) the pre-Messinian salinity crisis series (Mio). As elsewhere in the Mediterranean, the specific facies of the evaporitic Messinian series provide an excellent set of temporal markers for seismic interpretation.

The thickness of the PQ series gradually increases from $\sim 0.5$ to $\sim 1.2$ stwt landward and the Messinian series coincidently deepens toward the margin toe. The variable thickness of the Miocene series is maximum (0.8 stwt) at mid-profile $(\mathrm{km} 85)$. All these units are clearly post-rift sediments. No clear and continuous layering is imaged in the underlying acoustic basement $(\mathrm{AB})$, the top of which is irregular in the southern half of the profile, marked by a strong reflection, and onlapped by the Miocene series. This reflector extends under the slope at $~ 5.5$ stwt. As a main discordance between post-rift series and older terranes it is 
interpreted as the break-up unconformity in the continental crust of the margin, and as the top of the crystalline basement in the oceanic domain.

- Southern section: the narrow continental slope $(\sim 30 \mathrm{~km})$ is characterised by a wide $(15 \mathrm{~km})$ and thick (1.2 stwt) perched PQ basin overlying a chaotic, layered, 1.52.5 stwt-thick unit (CU) that passes laterally downslope into the Messinian series of the basin (km 115-125). The presence of both voluminous CU and perched basin marks a change in the continental slope, from a steep $\left(\sim 10^{\circ}\right)$ upper slope to a ledge at the top of the perched basin. The shelf break and the shelf that is very narrow in the study area ( 2 km; Figure 2) are out of the bounds of the MCS line. The seismic facies and stratigraphical position of the CU unit suggest that it could be an offshore extent of the olistostromes-bearing Numidian flysh units described onland (Bouillin et al., 1973; Bouillin, 1986) that would have been destabilised and emplaced at deep slope in Messinian times (Beslier et al., 2013). CU is structured by discontinuous southward dipping reflectors that are likely part of a flat-ramp system (FRS) associated with the tectonic inversion of the margin (Beslier et al., 2013). Therefore, the CU high that limits the perched basin downslope and marks a $\sim 1 \mathrm{~km}-\mathrm{high}$ continental slope-break ( $\mathrm{km} \mathrm{125)}$ is likely structural in origin and relates, at least partly, to compressional tectonics. Such a blind thrust system emerging near the slope toe, which is the first clear evidence for inversion-related structures in this part of the margin off NE Greater Kabylia, was previously proposed westward offshore Dellys and Boumerdes by Déverchère et al. (2005). As suspected by Domzig (2006) and shown by the overall flat geometry of BMU, no large-offset inversion-related structures are imaged further north in the deep basin.

- Northern section: conversely, the top of the acoustic basement is poorly defined in the northern half of the profile, the facies transition occurring underneath a zone deprived of MU diapirs (km 65 to 75; Figure 11). The northern end of the profile 
(km 0 to 40, Figure 10, and Figure 12 for uninterpreted section) is located in the sector of the Hannibal High $(\mathrm{HH})$, where the basement produces a strong amplitude magnetic anomaly (Galdeano and Rossignol, 1977) and is proposed to be a Cenozoic accretionary ridge by Mauffret et al. (2004). Although the base of the PQ series is well-marked by a clear change in seismic facies, the typical facies of the underlying Messinian evaporitic series, in particular MU diapirs, are not observed, as everywhere else in the Hannibal sector (Mauffret et al., 2004). The Pliocene series drapes the top of a high delineated by a low-amplitude and poorly layered chaotic seismic facies ( $\mathrm{VH}, \mathrm{km} \mathrm{30)}$ that can be interpreted as volcaniclastic sediments. Although the stratigraphical relation between Mio and $\mathrm{VH}$ are unclear, the main episode of $\mathrm{VH}$ emplacement ended before the Messinian, in agreement with the Tortonian age of the volcanic basement previously proposed by Mauffret et al. (2004). The surrounding Miocene series are characterised by higher amplitude reflections than in the southern part of the profile. The dome shape and outward thickening of the Miocene layering around VH high support an uplift of the acoustic basement during the Miocene that may have extended during the Plio-Quaternary. The VH seismic facies that extends at depth over a length of $\sim 20 \mathrm{~km}(\mathrm{~km} 20$ to 40) is limited northward by a strong, south-dipping reflector emerging under the Miocene series (km 20 to 25). Beneath VH, the uppermost acoustic basement is characterised by a $\sim 0.5$ stwt-thick seismic facies (VF) of high amplitude, discontinuous and hummocky reflectors interpreted as lava flows. These reflectors pinch out close to the northward end of the profile (km 10) and southward beneath $\mathrm{VH}(\mathrm{km} \mathrm{35)}$ where it may correlate to the south with the top of the acoustic basement. Deeper in the basement, the sub-horizontal reflective band between $\sim 6.5$ and 7.4 stwt may correspond to the Moho discontinuity (M), indicating a very thin basement ( 1.5 stwt) under VH. The Hannibal High then appears as a complex 
stacking of Miocene volcanic and volcaniclastic formations over a very thin crust, associated with a Miocene to recent, likely thermal, uplift. The terms 'Hannibal Ridge' used by Mauffret et al. (2004) being inappropriate to describe this internal structure and the subcircular contour of the related magnetic anomaly (see discussion below), it is called Hannibal High throughout this study.

The geometry of the three main interpreted interfaces, top of UU, BMU and top of AB, and the sea-bottom were used as initial constraints for the forward modeling.

\subsection{Velocity structure along the profile}

The final model from forward modeling of wide-angle seismic data from the Greater Kabylia SPIRAL profile allows us to image sedimentary geometries and crustal thickness down to a depth of $24 \mathrm{~km}$ along the forward model (Figure 4). The crustal thickness gradually decreases towards the north from $\sim 20 \mathrm{~km}$ at the margin toe to $4-5 \mathrm{~km}$ in the deep basin at 35-50 km model distance. Further north in the sector of the Hannibal High the crustal thickness slightly increases and the mean velocity slightly decreases. The complete sedimentary cover shows a variable thickness ranging from 2 to $4 \mathrm{~km}$, the thickest basin being located underneath the margin slope.

The final model from forward modeling comprises 8 layers, all identified by reflected and/or wide-angle phases in the multi-channel or wide-angle seismic datasets (Figure 4): the water layer, three sedimentary layers, three crustal layers and an upper mantle layer. The water layer was modeled using a velocity of $1.54 \mathrm{~km} / \mathrm{s}$ in good agreement with other studies in Mediterranean waters (Gailler et al., 2009, Dessa et al., 2011). The sedimentary layers, whose geometry is constrained by MCS data (Figure 10), are characterised from top to bottom by velocities between $2.0-2.2 \mathrm{~km} / \mathrm{s}, 4.1-5.0 \mathrm{~km} / \mathrm{s}$ and $2.5-4.0 \mathrm{~km} / \mathrm{s}$ in the PlioQuaternary, Messinian, and Miocene series, respectively. The second layer depicts a seismic velocity typical for evaporitic sediments, and a velocity inversion typical for the Messinian 
evaporitic layers that complicates accurate determination of the velocities in the underlying Miocene series. All layers thicken at the continental slope to form an up to $5 \mathrm{~km}$ thick sedimentary basin.

The highest crustal thickness of $24 \mathrm{~km}$ is imaged at $145 \mathrm{~km}$ model distance under the shelf break (Figure 4). From ray geometry only, it cannot be decided if crustal thickness increases further to the south. Three crustal layers were used to model P-wave velocities along the profile. Two of these layers representing upper and lower crusts are continuous throughout the model. A third layer was modeled with a $4.2-5 \mathrm{~km} / \mathrm{s}$ velocity on top of those two layers between model distance $0-30 \mathrm{~km}$ and $80-140 \mathrm{~km}$. It is characterised by a stronger velocity gradient than the underlying layers and therefore was modeled as an individual layer although no reflections have been detected from its base. From the correlation of this layer with the uppermost acoustic basement on the MCS data (Figure 10), it is likely that this layer is part of the crust in spite of its rather low velocities (see discussion below in sections 5.3.2 and 5.3.4). The underlying upper-crustal layer was modeled using velocities between $5.6-6.0 \mathrm{~km} / \mathrm{s}$ and the lower-crustal layer velocities between 6.0 and $6.8 \mathrm{~km} / \mathrm{s}$. As no reflection from the layer boundary could be identified, no or a very small velocity step was included into the model. However, two different velocity gradients were necessary to satisfactorily fit the data.

Crustal thinning is imaged between $45 \mathrm{~km}$ and $150 \mathrm{~km}$ model distance. The lateral variation of thinning is different in the two upper crustal layers and in the lower one. The two upper crustal layers include a region of very rapid thinning of $6 \mathrm{~km}$ along a width of only 10$20 \mathrm{~km}$ beneath the continental slope. Towards the north between 80 and $120 \mathrm{~km}$ the thinning of these layers is more gradual, and then the thickness is almost constant northward where the uppermost layer disappears. By contrast, thinning of the lower-crustal layer is more progressive than the upper ones, with a regular slope of the Moho of about $6^{\circ}$ increasing to $\pm 13^{\circ}$ underneath the continental slope. 
Towards the northern end of the profile, the crustal thickness possibly increases slightly from $4.0 \mathrm{~km}$ to about $5.5 \mathrm{~km}$ in the Hannibal sector, where the Moho geometry appears more irregular. Upper-crustal velocities in this region are between $4.2-5.0 \mathrm{~km} / \mathrm{s}$ for the upper layer and 5.5 - 5.8 for the second layer. Lower-crustal velocities vary between 6.2 and $6.6 \mathrm{~km} / \mathrm{s}$. The deepest layer corresponding to the upper mantle was modeled using velocities between 7.6 and $8.2 \mathrm{~km} / \mathrm{s}$. The lowest velocities of $7.6 \mathrm{~km} / \mathrm{s}$ were constrained to underlay the region of thin crust between 20 and $60 \mathrm{~km}$ model distance.

The velocity model reveals four main domains that can be identified by the number/thickness of layers and velocity/gradients in the layers (Figure 4). They consist from south to north of (1) the onshore continental crust (Domain 1) modeled by a two-layer crust under a thin sedimentary cover, (2) a zone of crustal thinning from 80 to $150 \mathrm{~km}$ model distance (Domain 2) where the Moho depth decreases from $24 \mathrm{~km}$ to $12 \mathrm{~km}$ towards the north under a 3-layer crust and the 3-layer sedimentary cover of the basin, (3) a region of very thin, 2-layer crust between 30 and $80 \mathrm{~km}$ model distance (Domain 3), and (4) the region of Hannibal High between 0 and $30 \mathrm{~km}$ model distance (Domain 4), where the crust includes a third uppermost layer. The nature of the crust deducted from the seismic data in all four domains is discussed below.

\subsection{Geological interpretation of the velocity model}

The nature of the crust in each domain is discussed from the velocity structure, including the geometry of the layers and of the Moho, the seismic facies on the coincident MCS profile (Figure 10), and by comparing 1D velocity-depth representative profiles extracted from below the top of the basement of the forward model to existing compilations for typical continental crust (Christensen and Mooney, 1995) and Atlantic-type oceanic crust (White et al., 1992) (Figure 4).

\subsubsection{Unthinned continental crust onshore the Kabylian margin}


The region from $150 \mathrm{~km}$ model distance up to the landward end of the profile corresponds to its onshore part (Domain 1, orange underlay in Figure 4). Here the crust is modeled by two layers of approximately similar thickness $(11 \mathrm{~km}$ and $13 \mathrm{~km})$ using velocities of 5.6 $6.0 \mathrm{~km} / \mathrm{s}$ and $6.3-6.6 \mathrm{~km} / \mathrm{s}$ and low vertical velocity gradients of $0.04 \mathrm{~km} / \mathrm{s} / \mathrm{km}$ in the upper-crustal layer and $0.02 \mathrm{~km} / \mathrm{s} / \mathrm{km}$ in the lower-crustal layer. The thickness of the crust is at least of $24 \mathrm{~km}$ that is the maximum thickness in the adjacent Domain 2. The sedimentary layer cannot be modeled because of the absence of reverse shots on land. A thin sedimentary layer was built in for the purpose of including land station delays from the underlying weathering layers. This is coherent with the Tizi Ouzou-Dellys sedimentary basin described onshore as a thin Miocene basin filled with marine series of 1000-1500 m maximum thickness (Aïte and Gélard, 1997).

The mean 1-D velocity model of this region fits well to existing compilations for extended continental crust (Christensen and Mooney, 1995), indicating a continental character of the crust in this region (Figure 4F). The ray geometry does not allow to verify if the crust south of $150 \mathrm{~km}$ model distance is still thickening, as expected compared to the topography onland, and in a crust supposed to be over-thickened by the AlKaPeCa collision and thrusting over the African paleomargin.

Unfortunately, no coherent arrivals were identified on the southernmost land stations of the profile located in the Tell domain. This excludes imaging the north dipping main thrust between the Internal Zones of the Kabylian block and the Tellian external domain that emerges at about $200 \mathrm{~km}$ profile distance. This might be related to strong seismic scattering when waves propagate across the thrust zone.

\subsubsection{Thinned continental crust of the Kabylian margin}

Between 80 to $150 \mathrm{~km}$ model distance (Domain 2, yellow underlay in Figure 4), the Moho depth decreases from $24 \mathrm{~km}$ to $12 \mathrm{~km}$ towards the north, resulting into crustal thinning from 
$\sim 23 \mathrm{~km}$ to $6 \mathrm{~km}$. The maximum Moho depth is constrained by arrivals from the upper mantle and the crust-mantle interface from six land stations. Throughout this domain, three distinct crustal layers were modeled. The uppermost layer has a thickness of about $2 \mathrm{~km}$ and is modeled using velocities between $4.2-5 \mathrm{~km} / \mathrm{s}$ that are lower than upper crustal velocities in Domain 1. The underlying layer is about $1.5 \mathrm{~km}$ thick and characterised by velocities between $5.2-6 \mathrm{~km} / \mathrm{s}$ and relatively low-velocity gradients of $\sim 0.5 \mathrm{~km} / \mathrm{s} / \mathrm{km}$. The lowermost layer was modeled using a velocity range between $6.3-6.6 \mathrm{~km} / \mathrm{s}$. Its thickness varies from about $6 \mathrm{~km}$ at $80 \mathrm{~km}$ model distance to over $10 \mathrm{~km}$ at $150 \mathrm{~km}$ model distance. The resulting vertical velocity gradient is of $\sim 0.04 \mathrm{~km} / \mathrm{s} / \mathrm{km}$. As the upper- and lower- layer velocities do not vary laterally in this domain, the resulting velocity gradients increase towards the north. However, this is most likely linked to the thinning of this layer rather than to a lateral change in lithology of the crust. All sedimentary layers thicken at the continental slope to form an up to $5 \mathrm{~km}$ thick sedimentary series that corresponds to the perched PQ basin and the underlying chaotic unit (CU) and Miocene sediments (Figure 10). The reduced velocity in $\mathrm{CU}$ under the deep slope ( $\mathrm{km} \mathrm{125)} \mathrm{may} \mathrm{be} \mathrm{related} \mathrm{to} \mathrm{fracturing} \mathrm{and} \mathrm{fluid} \mathrm{circulation}$ where the flat ramp system goes up toward the sea-bottom (Figure 10).

Velocities in this domain are intermediate between thinned continental and typical oceanic crust from data compilations (Figure 4E). However, the overall shape of the 1D velocitydepth functions in this part of the model is close to existing compilations for thinned continental crust with low gradients at depths larger than $2 \mathrm{~km}$ (Christensen and Mooney, 1995). Moreover, the regular slope of the Moho and coincident variation of the crustal thickness agree with a progressive thinning of the continental crust toward the continental breakup zone and support the continental affinity of the crust. The velocity structure is otherwise clearly different from that of exhumed mantle in ocean-continent transition (OCT) of magma-poor passive margins where the velocity gradient in the upper crust and the velocities at depth are much higher (Figure 4E; e.g., Dean et al., 2000; Sallarès et al., 
The top of the acoustic basement on the coincident MCS profile is clearly imaged by a strong amplitude reflector that draws topographic highs onlapped by the Miocene series (Figure 10). This unconformity at the base of the post-rift series can be interpreted as the breakup unconformity associated with the end of the extensional deformation of the continental crust. Accordingly, the underlying terranes are made of older syn- to pre-rift sediments and metamorphic rocks of the Kabylian basement, and the paleotopography is associated with syn-rift normal faults. The probable presence of syn-rift basins in the upper part of the acoustic basement can explain the mean low velocity of $4.2-5 \mathrm{~km} / \mathrm{s}$ modeled in this uppermost crustal layer. The high velocity gradient in this layer, especially where the crust is thinner than about $10 \mathrm{~km}$, might also be due to fracturing and hydration of the upper crust in this region. Similar seismic velocities and velocity gradients were modeled on the Atlantic continental margin off El Jadida, where drilling confirmed the continental nature and the fracturing of the basement (Contrucci et al., 2004). The velocities at mid-crustal level that are higher than mean value but in the range of continental crust velocities (Christensen and Mooney, 1995) could be related to the occurrence of some high grade metamorphic or ophiolitic rocks such as those described onshore in the Greater and Lesser Kabylia basement (e.g., Bouillin and Kornprobst, 1974; Saadallah and Caby, 1996; Caby et al., 2001; Abbassene et al., 2016, and references therein).

The Algerian margin off Greater Kabylia therefore includes a $50 \mathrm{~km}$ wide deep margin of thinned continental crust at the foot of the continental slope. This singles out this segment from the other ones of the Algerian margin where the continental breakup zone is close (around $10 \mathrm{~km}$ ) to the slope toe and almost no deep margin of thinned continental crust was imaged (Leprêtre et al., 2013; Mihoubi et al., 2014; Badji et al., 2015; Bouyahiaoui et al., 2015). 


\subsubsection{Transition between continental and oceanic domains}

From the geological interpretation of the velocity model, the transition between the continental and the oceanic crust is inferred to occur between Domains 2 and 3, at about $80 \mathrm{~km}$ model distance where the low velocity uppermost continental crust layer pinches out (Figure 4). It appears to be a sharp transition, or a less than $20 \mathrm{~km}$-wide transition from the horizontal resolution of the velocity model. On the MCS data, the top of the acoustic basement displays a change of seismic pattern in the same area, at about $70 \mathrm{~km}$ profile distance, from a strong reflection southward (thinned continental crust) to poorly imaged northward (thin oceanic crust)(Figure 11).

\subsubsection{Thin crust underlying the Algerian basin}

Between $30 \mathrm{~km}$ and $80 \mathrm{~km}$ (Domain 3, light blue underlay in Figure 4), the crust is modeled using two distinct layers and velocities of 5.5 to $5.8 \mathrm{~km} / \mathrm{s}$ and 6.0 to $6.7 \mathrm{~km} / \mathrm{s}$ with a gradient of $\sim 0.2 \mathrm{~km} / \mathrm{s} / \mathrm{km}$ in both layers. This is the domain where the crust is the thinnest $(<4 \mathrm{~km})$ and where the uppermost mantle velocity is low $(7.6 \mathrm{~km} / \mathrm{s})$. The crustal thickness variation, between 3.5 and $6 \mathrm{~km}$, depends mainly on the lower layer thickness. It can be observed that where the crust is the thinnest, both crustal layers have an almost identical thickness.

Velocities in this domain are higher than those of extended continental crust and 1D velocity models fit with the existing compilations for Atlantic-type oceanic crust (Figure 4D) (White et al., 1992). The low gradient and high velocities in the upper crustal layer are in the upper bound of the values for Layer 2, and in the lower-crustal layer gradient is close and velocities are in the lower bound of the values for Layer 3. However the thickness of the crust is only $3.5-6 \mathrm{~km}$, thus about $2-3 \mathrm{~km}$ thinner than the $7 \mathrm{~km}$-thick normal oceanic crust (White et al., 1992) (Figure 4D).

This type of crust is mainly produced in magma-poor environments such as slow- to ultraslow spreading centres where the crust, and particularly Layer 3, tends to be a mix of partly 
serpentinised peridotites and intrusive gabbro plutons (e.g. Cannat, 1996). Partly

serpentinised mantle can also be exhumed at the OCT of magma-poor passive margins, such as the West Iberian margin (e.g., Boillot et al., 1989; Dean et al., 2000; Sallarès et al., 2013). In the absence of direct identification by rock sampling, and of converted S-wave arrivals in the recordings, discriminating between serpentinised mantle peridotite and gabbroic crust is problematic using only crustal thickness and velocities as they are not discriminant criteria. Indeed, the maximum depth at which fracturing and water circulation allow substantial serpentinisation ( $\pm 5 \mathrm{~km}$, e.g. Francis, 1981; Minshull et al., 1998) is close to the mean thickness of a magmatic crust in the oceanic domain $(\sim 7 \mathrm{~km})$, and velocity fields overlap between 6.1 and $7.5 \mathrm{~km} / \mathrm{s}$ for gabbros and serpentinised peridotites containing 10 to $40 \%$ of serpentine (Horen et al., 1996). Off Greater Kabylia in Domain 3 the thin crust is modeled with a maximum velocity of $6.7 \mathrm{~km} / \mathrm{s}$ in Layer 3 that in itself is not discriminating. However, the overall shape of the 1D depth-velocity profiles departs clearly from those in exhumed upper mantle in which decreasing degree of serpentinisation with depth is characterised by (1) high velocity gradients in the upper part of the seismic crust, passing gradually to high velocities in the lower part increasing up to values of the order of $7.5 \mathrm{~km} / \mathrm{s}$, and (2) the absence of a velocity step at the seismic Moho that represents the limit between serpentinised and unserpentinised mantle (i.e. the serpentinisation front, see e.g. Chian et al., 1999; Dean et al., 2000; Van Avendonk et al., 2006; Prada et al., 2014; Sallarès et al., 2013) (Figure 4D). By contrast, the much lower gradient and maximum velocity in the upper crustal layer of Domain 3 and two velocity steps at both an intra-crustal and the Moho transitions suggest that the seismic crust in Domain 3 is not dominantly composed of partly serpentinised peridotites. Two other characteristics of the thin crust off Greater Kabylia strengthen this hypothesis: a variable thickness of Layer 3 is often imaged in ultraslow accreted crusts (e.g. Mutter and Mutter, 1993, Klingelhoefer et al., 2000a, b), and the Moho is well marked by a velocity step and the occurrence of some reflections from the 
Moho (PmP arrivals) on the wide-angle data. The Moho corresponds also to a set of reflections on the MCS data as a sub-horizontal reflective band between $\sim 6.5$ and 7.4 stwt in the northern adjacent Domain 4 (Figure 10) that corresponds to the Moho depth on the velocity model (Figure 4). One may note however that this reflective band seems to exist also in the southern part of Domain 3 ( $\mathrm{km} 65$ to 75$)$ but vanishes in between, where the crust is the thinnest and the velocity modeled in the uppermost mantle is low $(7.6 \mathrm{~km} / \mathrm{s}$; Figures $4 \mathrm{C}$ and D), both supporting mantle serpentinisation. Indeed, $4 \mathrm{~km}$ crustal thickness is sufficiently small to allow for brittle cracks to pass the entire crust, thus allowing seawater penetration and serpentinisation of the upper $5 \mathrm{~km}$ of mantle (Minshull et al., 1998). A velocity of $7.6 \mathrm{~km} / \mathrm{s}$ in the uppermost mantle corresponds to about $10 \%$ of serpentinisation based on laboratory measurements (Christensen, 1966; Horen et al., 1996). The low crustal thickness and velocity in Layer 3 may then indicate some amount of altered mantle within it. A second explanation of anomalous low upper mantle velocities is the existence of a thermal anomaly as would be required underneath recent volcanic edifices.

The last striking feature of 1D velocity-depth functions in Domain 3 is the low velocity gradient in oceanic Layer 2, in particular in the northern part of the domain (Figure 4D). The gradient in Layer 2 is generally related to porosity in basalts that decreases with age due to the closure and infilling of cracks and pores by secondary hydrothermal mineralization (e.g. Carlson and Herrick, 1990). In Domain 3, the gradient is even lower in 1D models extracted where the crust is the thinnest (close to Hannibal High) than in two 1D models extracted southward (in dark red on Figure 4D). The proximity of Hannibal High may have resulted in an increase in hydrothermal activity leading to the filling of pore spaces and thereby an increase in the upper layer velocity of Layer 2 together with a decrease of the velocity gradient in this layer (see section 5.3.5. below).

The thin crust in Domain 3 is then clearly of oceanic affinity. It is modeled by two layers that share characteristics with Layers 2 and 3 of thin crusts accreted at slow to ultra-slow 
spreading ridges that can include a variable amount of serpentinised peridotites.

\subsubsection{The Hannibal High at the northern end of the model}

Between 0 and $30 \mathrm{~km}$ model distance (Domain 4, dark blue underlay in Figure 4), three layers were modeled using velocities higher than $4.2 \mathrm{~km} / \mathrm{s}$ corresponding to crustal layers. The $\sim 1.25 \mathrm{~km}$ thick uppermost layer, which does not exist in the neighbouring Domain 3 , is characterised by lower velocities $(4.2-5.0 \mathrm{~km} / \mathrm{s})$ and much higher gradients than in the deeper layers. The $1.5 \mathrm{~km}$-thick intermediate layer displays velocities between 5.5 and $5.8 \mathrm{~km} / \mathrm{s}$ and a vertical velocity gradient of $0.2 \mathrm{~km} / \mathrm{s} / \mathrm{km}$. Finally, the $\sim 2-3 \mathrm{~km}$ thick lowermost layer displays velocities ranging between 6.2 and $6.6 \mathrm{~km} / \mathrm{s}$ and a vertical velocity gradient of $0.3 \mathrm{~km} / \mathrm{s} / \mathrm{km}$. The deeper sedimentary layer, whose thickness and velocity increase in the northern part of neighbouring Domain 3, thins where the uppermost crustal layer thickens.

The 1D velocity-depth functions from this region match the envelope of compilations for Atlantic-type oceanic crust (White et al., 1992) (Figure 4C). However, the velocity in the lowermost crust is slightly lower than the compilation bound, and a three-layer velocity distribution including an uppermost layer with a high gradient and two deeper layers with lower gradients is unusual for 'normal' oceanic crust. Compared to Domain 3, velocities and gradients are similar in the two lower layers, and the increase in crustal thickness of 1$2 \mathrm{~km}$ is mainly due to the appearance and thickening of the uppermost layer and to slight lower-layer thickening (Figure 4).

On the MCS SPI11 profile, the uppermost crustal layer corresponds to the thin reflective seismic facies VF interpreted as lava flows that deepens and extends southward under the VH volcaniclastic facies and pinches out just south of it (Figures 10,12). This suggests that lava flows and volcaniclastic series were poured over an existing oceanic basement. This hypothesis is supported by the 1D velocity-depth profiles in Domains 3 and 4 . Indeed, the 
Vz-profiles in the Hannibal region (Domain 4) are similar to those in Domain 3 if the uppermost crustal layer is removed and the velocity profiles correspondingly shifted upward (Figure 13). Doing so, the velocity in the lowermost crust of Hannibal Ridge also matches the velocity range for Atlantic-type oceanic crust (Figure 4).

The VH poorly layered chaotic seismic facies corresponds to a positive magnetic anomaly and to the slight velocity increase up to $\sim 4 \mathrm{~km} / \mathrm{s}$ modeled in the Miocene series at $40 \mathrm{~km}$ model distance (Figure 4). This value is in the range for volcaniclastic and hyaloclastic rocks, whose velocities are highly variable and span from 2.2 to $5.0 \mathrm{~km} / \mathrm{s}$ (e.g., Jerram et al., 2009; Planke et al., 1999, 2000). This slightly higher velocity is also modeled in the surrounding Miocene sedimentary series, where it may relate to interbedded volcaniclastic layers that could cause the high-amplitude reflections of the Miocene seismic facies in the Hannibal region (Figures 10 and 12), as described around Gran Canaria (Funck et al., 1996). However, it is recalled here that the velocity is poorly constrained in this layer due to velocity inversion under the evaporitic Messinian series. The step-back in first arrivals in record sections from the Hannibal region indicates that Messinian evaporitic series are included in the sedimentary cover. The absence of diapirs may be due either to a reduced thickness of the salt layer (Mauffret et al., 2004) or to higher thermicity that may have caused a change in the composition and rheological properties of the evaporites. Assuming that $\mathrm{VH}$ is part of the Hannibal massif, the limit between Domains 3 and 4 is shifted $20 \mathrm{~km}$ southward (Figure 10).

The underlying VF facies corresponds to the uppermost crustal layer where velocities are modeled between 4.2 and $5 \mathrm{~km} / \mathrm{s}$. It forms a $\sim 1 \mathrm{~km}$-thick sheet-like body that extends over at least $30 \mathrm{~km}$, with locally a high amplitude, smooth top onlaped by the overlying VH reflections, and internal high amplitude, discontinuous and hummocky reflectors, similar to the seismic facies of lava flows (e.g. Planke et al., 2000). Velocities in such volcanic formations vary in a cyclic way, each individual flow being characterised by a velocity 
increase from $2-3 \mathrm{~km} / \mathrm{s}$ in the porous and weathered top to $5-6 \mathrm{~km} / \mathrm{s}$ in the fresh and more massive middle-flow basalt, and a rapid velocity decrease near the base (Planke et al., 1999). Velocity and density top and bottom gradients are largely independent of flow thickness, implying that the average velocity in the flows stack depends mainly on the relative amount of fresh and massive basalt, thus on the thickness of the flows (Planke et al., 1999). The gradient modeled in the uppermost crustal layer in Hannibal region may therefore be related to an upward decrease in the thickness of the lava flows.

Therefore, from our new wide-angle and vertical seismic data, the Hannibal sector appears to be floored by a thin $(4-4.5 \mathrm{~km})$ oceanic crust similar to the one found in Domain 3 , overlain by volcanic flows and volcaniclastics whose thickness reaches $\sim 3 \mathrm{~km}$ along the SPIRAL transect. A greater accuracy on the southern limit of the Hannibal volcanic massif is given by the southward extent of the VH and possibly the VF seismic facies on the MCS data, up to about $40 \mathrm{~km}$ profile distance. The geometry of the Miocene and Plio-Quaternary series surrounding VH shows that the main volcanism episode occurred during the Miocene and ended before the Pliocene. Uplift and possible fluids circulation imaged in the PlioQuaternary series strongly suggest however that a thermal anomaly still persists nowadays.

\section{Discussion : implications for the margin/basin structure and formation}

\subsection{Thin oceanic crust in the Algerian basin}

The crust underlying the Algerian basin off Greater Kabylia is of oceanic affinity, as imaged on all the SPIRAL wide-angle seismic sections spread along the margin from Mostaganem to the west to Annaba to the east (Leprêtre et al., 2013; Mihoubi et al., 2014; Badji et al., 2015; Bouyahiaoui et al., 2015). Crustal thickness varies from 3-4 km in the Mostaganem and Greater Kabylia sectors (see location on Figure 1) to a maximum of $\sim 5.5 \mathrm{~km}$ offshore 
Tipaza and Annaba, the variability depending mainly on the thickness of Layer 3

(Figure 14C; Leprêtre et al., 2013; Mihoubi et al., 2014; Badji et al., 2015; Bouyahiaoui et al., 2015; this study). The oceanic crust offshore Algeria is thinner than the $7 \mathrm{~km}$ average value for typical oceanic crust (White et al., 1992, Figure 14A) and displays a two-layer structure that can be interpreted as representing oceanic layers 2 and 3 (Figure 14C; Leprêtre et al., 2013; Mihoubi et al., 2014; Badji et al., 2015; Bouyahiaoui et al., 2015; this study). This interpretation is consistent with results from older wide-angle data indicating a 5 to $6 \mathrm{~km}$-thick oceanic crust in the north Algerian basin (Hinz, 1973; Vidal et al., 1998; Grevemeyer et al., 2011) and disagrees with the continental affinity of the basin floor proposed locally by Roure et al. (2012).

The thin oceanic crust of the Algerian basin shares many similarities with thin oceanic crusts produced at ultra-slow spreading centres, such as the present-day active South-West Indian Ridge (SWIR; Muller et al., 1997) and Mohns Ridge (Klingelhoefer et al., 2000a, 2000b) (Figure 14 B), or extinct spreading centres as the Labrador Sea ridge (Delescluse et al., 2015), Aegir Ridge (Grevemeyer et al., 1997) and Gakkel Ridge (Jokat et al., 2003). In such magma-poor environments, the reduced to episodic partial melting of the mantle is understood to be due to conductive heat loss related to slow spreading rates and to a relatively colder asthenosphere (Purdy et al., 1992; Bown and White, 1994). Accretion in such a slow and/or cold environment results into a thin crust whose formation is controlled by both tectonics and magmatism and is highly variable in structure and thickness (particularly for Layer 3), with variable amounts of serpentinised peridotites (e.g., Cannat, 1996; Muller et al., 1997; Minshull et al., 1998; Klingelhoefer et al., 2000a). It also produces irregular magnetic anomalies of highly variable intensity (Jokat and SchmidtAursch, 2007), as observed in the magnetic pattern of the Algerian basin (Schettino and Turco, 2006). All these similarities point to a cold and/or slow environment at the birth of the Algerian oceanic crust. 
Although the poorly organized magnetic pattern of the Algerian basin prevents from estimating accretion rates (Schettino and Turco, 2006 and references therein), the environment during the opening of the basin is typical of back-arc settings. Indeed, thin oceanic crusts with variable thickness are found in many back-arc basins, at very-slow to fast spreading rates, such as the Lau basin (Turner et al., 1999; Crawford et al., 2003), the Philippine Sea and the Parece Vela basin (Louden, 1980), the Japan Sea (Hirata et al., 1992), and all western Mediterranean basins (e.g., Hinz 1973; Vidal et al., 1998;

Grevemeyer et al., 2011; Prada et al., 2014) (Figure 14C, D, E and F). For instance, crustal thicknesses found in the Liguro-Provençal basin vary from 4 to $6 \mathrm{~km}$ (Pascal et al., 1993; Contrucci et al., 2001; Dessa et al., 2011; Gailler et al., 2009; Afilhado et al., 2015; Moulin et al., 2015) (Figure 15) and velocity-depth profiles are similar to those in the Algerian basin (Figure 14D and F). Moreover, unusually low mantle temperatures due to the subduction of a cold slab have been proposed to explain the anomalously thin oceanic crust in the Philippine Sea basin (Sclater et al., 1976; Louden, 1980) and in the Provençal basin (Gailler et al., 2009). We therefore postulate that the thin oceanic crust along the Algerian margin relates to the back-arc opening setting of the Algerian basin arising from the rollback of the Tethyan slab.

In spite of large-scale similarities, some variability in the structure of the oceanic crust is observed along the margin, in particular between the WAB and EAB sub-basins. The 1-D velocity models compiled on Figure $14 \mathrm{C}$ show that velocities are higher and gradients lower in Layer 2, and gradients are slightly lower in Layer 3 in the WAB (Great Kabylia and Tipaza transects; see location on Figure 1) than in the EAB (Jijel and Annaba transects). In the WAB, the seismic signature of the Moho in the lower crust off Mostaganem (Badji et al., 2015) and the low velocities in the uppermost mantle off Greater Kabylia (this study; Figures 4 and 14C) suggest some serpentinised mantle within a comparably thin (3-4 km) crust. No serpentinisation is reported in between, off Tipaza (Leprêtre et al., 2013), but the 
higher crustal thickness of $5.5 \mathrm{~km}$ corresponds to the threshold value at which substantial hydrothermal alteration of the underlying uppermost mantle is impossible $( \pm 5 \mathrm{~km}$, e.g. Francis, 1981; Minshull et al., 1998). By contrast, the characteristics of the oceanic crust in the EAB offshore Jijel and Annaba favor a dominantly magmatic thin crust including little or no serpentinised mantle (Mihoubi et al., 2014; Bouyahiaoui et al., 2015). These results first strengthen the hypothesis of two distinct sub-basins, the EAB and the WAB, that was earlier proposed from the magnetic pattern (Schettino and Turco, 2006). Secondly, they allow to better locate the limit betweeb both sub-basins earlier located in the $\mathrm{HH}$ area (Cohen, 1980; Schettino and Turco, 2006). Actually, the WAB affinity of the crust off Great Kabylia supports a limit located in between the Great Kabylia and Jijel SPIRAL profiles.

This variability in the structure of the oceanic crust between the WAB and the EAB also supports two different modes of seafloor emplacement. In the EAB, the characteristics of the oceanic crust suggests a dominantly magmatic thin crust such as the crust generated at Mohns Ridge in a slow but hot environment (Kingelhoefer et al., 2000; Bouyahiaoui et al., 2015). There, a set of lineated NW-SE magnetic anomalies off Jijel and Annaba (Galdéano and Rossignol, 1977; Schettino and Turco, 2006) led Bouyahiaoui et al. (2015) to propose an emplacement of the EAB in a one-step evolution model, before the collision of the forearc domain (the Lesser Kabylia at that place) during the southeastward rollback of the Tethyan slab (insets in Figure 1). A slab tear at depth, due to the increasing trench-length of the subduction zone during its curvature, would be responsible for the hot accretion setting. For the WAB, we discuss in the next section the compatibility of our results with a two-step evolution as proposed from the structure of the Algerian margin off Tipaza (Leprêtre et al., 2013).

\subsection{Post-accretion volcanism in the Hannibal sector: two-step opening of the}

\section{West Algerian basin}

The 3-layer structure of the oceanic crust in the Hannibal sector (Domain 4) likely results 
from stacking of lava flows over a thin crust similar to that of Domain 3, together with volcaniclastic and/or hyaloclastic products included in the Miocene sedimentary cover of the velocity model (Figures 10,12,13). The lack of clear intercalated sedimentary series below VF suggests that volcanism occurred just or shortly after accretion of the crust, which is indirectly dated at about $17-18 \mathrm{Ma}$ in the Algerian basin using data sampled at the coastline (Bruguier et al., 2009; Abbassene et al., 2016; Chazot et al., 2017). According to the wedge-shaped geometry of the Miocene series around VH and the sealing by the Messinan series, the main emplacement episode of the volcanism is dated of Middle to Late Miocene, but thermal uplift and hydrothermal activity seems to extend during PlioQuaternary (Figures 10, 12). There is no evidence for magmatic underplating in the Hannibal sector from the seismic data.

The Hannibal region in the easternmost part of the WAB is also characterised by a $\sim 70 \mathrm{~km}$ wide, sub-circular, group of high amplitude positive magnetic anomalies (Figure16; Galdéano and Rossignol, 1977). It is one of the largest and strongest anomalies that characterise the irregular magnetic pattern in the WAB. The magnetic anomaly that correlates with the VH volcaniclastic facies along the SPI11 profile is part of this group of positive anomalies (Figures 4, 10 and 16). These observations strongly suggest that the complete set of anomalies in the Hannibal sector was created at the same time and is related to Middle to Late Miocene volcanism. Such volcanism implies partial melting in the underlying mantle. Conversely, these observations do not support the hypothesis of the Hannibal 'Ridge' being a N-S oriented, asymmetric, accretionary ridge as proposed by Mauffret et al. (2004) from older and sparse seismic reflection data. According to these authors, a first rifting stage moved the Maghrebian internal blocks (the AlKaPeCa unit) toward the SE, leading to the collision of the Kabylies with the African margin.

Oceanisation would have occurred afterwards between 16 and 8 Ma owing to the fast westward rollback of the Gibraltar arc, with the Hannibal volcanic feature being interpreted 
as a N-S trending accretion ridge. A highly asymmetric accretion process is implied by the eastern position of the Hannibal ridge in the WAB.

The structure of the oceanic crust revealed in the Hannibal sector by the new SPIRAL wideangle and MCS data, together with the magnetic data, supports a 2-step evolution model but do not display evidence for a N-S oriented accretion ridge (Figures 10, 16). The peculiar 3layer seismic structure of the oceanic crust rather suggests that an oceanic basin floored by a thin oceanic crust formed during the first back-arc opening stage linked to the southward rollback of the Tethyan slab and until the collision of the Kabylides terranes with Africa, and that this oceanic basement was remobilized during the second stage of westward rollback, i.e. after $17 \mathrm{Ma}$ (Abbassene et al., 2016; Chazot et al., 2017). We propose that during this second stage, partial melting in the underlying mantle gave rise to the emplacement of stacked lava flows and volcaniclastic sediments over the previous oceanic crust. Remobilization may have also triggered normal faulting revealed by some wedgeshape Miocene series on SPI11 and en-echelon N-S fabric suggested by Mauffret et al. (2004), possibly leading to an over-thinning of the oceanic crust.

Onland Miocene magmatism is known westward of the study area in the Dellys region (Figure 2). It includes basaltic and andesitic lava flows, basaltic hyaloclastic breccias and pyroclastic deposits that are either interbedded within or overlie Miocene deposits and are dated between 15.6 and 11.8 Ma (Chazot et al., 2017 and references therein). Eastward of the study area (Bejaia area), a volcanoplutonic complex includes an upper part of pyroclastic rocks over plutonic bodies dated between 16.8 and 14 Ma. Both massifs are associated with a positive magnetic anomaly (Figure 16). The volcanic rocks in these massifs are among the more mafic ones, and thus less affected by crustal contamination, of the Miocene magmatism in the Kabylies. These calc-alkaline rocks, whose age and characteristics are typical of post-collisional magmatism, most probably result from partial melting of the Kabylian lithospheric mantle previously metasomatised during the southward 
rollback opening phase (Abbassene et al., 2016; Chazot et al., 2017). These authors propose that partial melting in the mantle would have been triggered by asthenospheric upwelling due to lithospheric delamination and slab tear that followed the Kabylies collision at 17 Ma. Moreover, most onland Miocene magmatism in the Kabylies occurred in the area where recent tomographic studies suggest a segmentation and an offset in the upper part (200-300 km) of the detached African slab beneath the Algerian margin (Fichtner and Villaseñor, 2015). Therefore, these similarities in age, facies and setting lead us to propose that the post-accretion volcanism in the Hannibal region is an offshore equivalent of the onshore post-collisional calc-alkaline volcanism. The position of the Hannibal region at the eastern tip of the western segment of the African slab identified by Fichtner and Villaseñor (2015) (Figure 16) supports a partial melting in the mantle triggered by asthenospheric upwelling in the slab tear. The Hannibal magnetic anomaly being one of several strong positive anomalies characterizing the irregular magnetic pattern of the WAB (Figure 16; Galdéano and Rossignol, 1977; Schettino and Turco, 2006), at least part of these anomalies may also originate from post-accretion volcanism and would evidence irregularly distributed spots of deep partial melt in the metasomatised mantle underlying the basin. Accordingly, diffuse spreading would have occurred during the second (westward) stage of slab rollback rather than accretion along a single organised spreading center.

Our results thus agree with a two-step evolution of the WAB as proposed from the structure of the Algerian margin offshore Tipaza (Leprêtre et al., 2013) or from tomographic and kinematic studies (Faccenna et al., 2004; Spakman and Wortel, 2004; van Hinsbergen et al., 2014). An oceanic crust would have been accreted during the first (southward) back-arc opening stage, that was magmatically, and probably tectonically, reworked during the second westward back-arc opening stage, forming sparse magmatic and volcanic spots.

\subsection{The ocean-continent transition (OCT)}

None or only few evidence for syn-rift magmatism has been identified along the Algerian 
continental margin. The oldest magmatism onland is dated at $17 \mathrm{Ma}$ and is clearly identified as post-collisional (Chazot et al., 2017 and references therein). The seismic data do not image underplating or seaward-dipping reflectors in the deep offshore margin (Leprêtre et al., 2013; Mihoubi et al., 2014; Badji et al., 2015; Bouhiayaoui et al., 2015; this study). Therefore the Algerian margin is a magma-poor or amagmatic margin.

As known for such margins, continental mantle exhumation may occur in the OCT just after the continental breakup and before the onset of true, steady-state oceanic accretion, as a probable consequence of slow extension rates and/or the proximity of relatively cold subcontinental mantle (e.g. Boillot et al., 1989; Cannat et al., 2009). Although serpentinised mantle may locally compose the thin oceanic crust of the WAB (Badji et al., 2015; this study), there is no evidence for exhumation of mantle material in the continental breakup zone (Leprêtre et al., 2013; Badji et al., 2015; this study). The narrow or even absent OCT along the Algerian margin suggests that the onset of oceanic accretion occurred immediately after the breakup of the continental crust of the margin.

However, the two-step evolution proposed for the WAB may not have preserved the initial geometry of the deep margin created during the first southward rollback stage. As proposed by Leprêtre et al. (2013) in the neighbouring segment of the margin off Tipaza, the initial oceanic crust or even the deepest part of the continental margin may have been drifted toward the west along a sinistral wrench zone created along the margin at the tip of the subducting slab during the second step of westward rollback (inset c in Figure 1). Whether this wrench fault zone is part of the STEP-fault system proposed to explain the structure of the westernmost segment of the Algerian margin in the Mostaganem area (Medaouri et al., 2014; Badji et al., 2015) is a matter of debate and depends on the initial lateral extent of the Tethyan subduction, as discussed by van Hinsbergen et al. (2014). The segments of African slab recently identified under the central part of the Algerian margin (Fichtner and Villaseñor, 2015) suggest that the STEP system associated with the curvature of the slab 
under the Alboran basin would have initiated westward of the Kabylies. However, in this case, strike-slip movement along the Greater Kabylia margin may have occurred far inside the upper plate in response to the free border created at the western limit of the westward rollback system.

\subsection{Margin structure and inversion}

In the study area, the first-order structure of the central part of the Algerian margin is that of a rifted continental margin, with a thinning of the continental crust from a thickness of more than $24 \mathrm{~km}$ at the coastline to 5-6 km at the OCT (Figure 4). Continental crustal thickness in the adjacent segments of the margin is at least $20 \mathrm{~km}$ westward near Tipaza (Leprêtre et al., 2013) and at least $23 \mathrm{~km}$ eastward near Jijel (Mihoubi et al., 2014), therefore comparably thin as in our study region.

Leprêtre et al. (2013) explain the thin crust along the Tipaza margin by: (1) thinning by back-arc extension of crustal blocks accreted to previously active-type margins (Gailler $e t$ al., 2009; Pepe et al., 2010) and (2) inheritance from the African passive margin that included a thinned continental domain before collision with the Kabylian block. They have also suggested that the undercompensation of the margin on land could be related to the thermal effect of the break-off of the Tethyan slab around $16 \mathrm{Ma}$ (e.g., Carminati et al., 1998a,b; Maury et al., 2000; Fichtner and Villaseñor, 2015). Moreover, Hamai et al. (2015) attribute the undercompensation of the whole margin on land to a flexural response to the Plio-Quaternary compressional reactivation. All these factors may contribute to explain the shallow position of the Moho in the continental domain of Greater Kabylia in the study area.

Even if twice wider than on the other segments of the margin, the Algerian margin on the Greater Kabylia transect is only $70 \mathrm{~km}$-wide, which is 50 to $100 \mathrm{~km}$ less than the mean width of Atlantic-type margins (e.g. Funck et al., 2004; Biari et al., 2015; Klingelhoefer et 
al., 2015) but in the same range than most of the western Mediterranean margins (e.g. Gailler et al., 2009) (Figure 15). The slope being similarly steep along the complete Algerian margin, the larger width of the margin offshore Greater Kabylia correlates with a wider deep domain of thinned continental crust (Domain 2 in Figure 4) than on the other segments of the margin. The occurrence of fractured basement and/or of syn-rift sediments may explain the low velocities in the uppermost crustal layer.

The thinned continental crust in this domain displays a unique asymmetric geometry, with a differential thinning of the upper and lower seismic crustal layers: the thickness of the upper seismic crust is reduced by about half over a width of $10 \mathrm{~km}$ under the continental slope while that of the lower seismic crust decreases progressively over the $70 \mathrm{~km}$ of width of Domain 2 (Figure 4). This results into a much gentler slope of the Moho than of the basement top, and thus in a strong vertical asymmetry of the crustal neck that is unusual for rifted continental margins. The same trend is observed, over a more reduced width, along the Jijel (Figure 6 in Mihoubi et al., 2014) and the Tipaza (Figure 7 in Leprêtre et al., 2013) transects, and possibly on the westernmost Mostaganem transect (Figure 7 in Badji et al., 2015) (Figure 15).

Considering the complex evolution and geodynamic setting of the Algerian margin, the processes responsible for this unique geometry may be multiple and/or composite.

However, according to a recent isostatic analysis, it may originate in the last stage of inversion of the margin that prevails since early Pliocene due to ongoing Africa-Eurasia convergence (e.g. Déverchère et al., 2005; Yelles et al., 2009). Using four of the velocity models obtained from the wide-angle SPIRAL data (Leprêtre et al., 2013; Mihoubi et al., 2014; Bouyahiaoui et al., 2015; this study), Hamai et al. (2015) have performed an isostatic analysis and a flexural modeling along the margin. Their results highlight an isostatic disequilibrium that reaches a maximum amplitude on the Greater Kabylia transect and can be the result of opposite flexures of two plates decoupled at the continental slope 
(Figure 17). Flexural modeling predicts a $6 \mathrm{~km}$ downward deflection of the north oceanic plate at the foot of the slope off Greater Kabylia. A concomitant progressive thickening of the Plio-Quaternary sedimentary series, from 0.5 stwt to $\sim 1$ stwt, is observed toward the slope (Figure 10). The decoupling zone between the two plates at the deep, distal margin coincides with the upper part of the blind thrust system identified under the continental slope (Figure 10). These deflection and associated disequilibrium result from the elastic response of the lithosphere to the compressive stress field, which is also accommodated by permanent deformation along thrust systems in the deep continental margin. These structural features may potentially lead to the initiation of a southward subduction of the oceanic crust of the basin under the margin, as previously suggested by Auzende et al. (1972), Déverchère et al. (2005), Domzig et al. (2006), Yelles et al. (2009), Strzerzynski et al. (2010), Billi et al. (2011) and Hamai et al. (2015).

The isostatic analysis of Hamai et al. (2015) provides an estimate of the amount of deflection that should be substracted from the observed Moho to bring it to an isostatically compensated 'unflexed' position. Applying this correction to the Greater Kabylia profile significantly changes the geometry of the Moho, as illustrated on Figure 17. The corrected geometry tends towards a vertical symmetry of the crustal neck with a steeper slope of the Moho over a reduced width beneath the steep slope of the top of the basement. The same trend is obtained by applying this correction to the neighbouring Jijel and Tipaza transects. Accordingly, the peculiar asymmetrical shape of the crustal neck is a response to the isostatical disequilibrium and the associated vertical movements related to the plate convergence and may thus be a characteristic feature of inverted rifted margins.

Finally, if the vertical asymmetry of the crustal neck is a consequence of the margin inversion, it cannot be attributed to depth-dependent stretching during the rifting of the margin that would have overthinned the upper crust with respect to the lower one. Although an equivalent correction to that of the Moho should also be applied to shallower main 
interfaces (top of the basement and of Miocene series) in order to obtain a more precise geometry of the isostatically compensated margin, the correction of the Moho is enough to show that the main consequence of the isostatic disequilibrium is an increase in the volume of the lower continental crust (Figure 17). Two processes can be invoked to explain increased volume of lower crust in rifted continental margins: magmatic underplating, and plastic flow of lower continental crust toward the deep, distal margin. The seismic structure of the margin rules out the first process. Indeed, no indications of voluminous underplated body is shown by the velocity model, such as high seismic velocities $(7.4-7.8 \mathrm{~km} / \mathrm{s})$ at the base of the thinned continental crust or double reflections from the top and base of such a body (Figure 4) as found along typical volcanic margins (e.g. White et al., 1987;

Klingelhoefer et al., 2005). Also, as pointed out before, only a moderate, post-rift, magmatic activity is known onland (Chazot et al., 2017). The most likely hypothesis is thus lower crustal flow. Hopper and Buck (1998) define a diffuse decoupling mode occurring in rifted margins when the lower crust flows laterally in response to pressure gradients induced by topography and crustal thickness variations. Modeling of this decoupling mode shows that lower crustal flow might be expected for a range of heat flow values when the continental crust is $30 \mathrm{~km}$ thick, and when quartz, or even anorthosite and diabase, is the dominant crustal mineralogy. For those two latter more competent mineralogies, a higher temperature $\left(>750^{\circ} \mathrm{C}\right)$ is needed at the crust-mantle boundary. As a high heat flow most probably prevailed during the recent evolution of the Algerian margin due to slab tear and segmentation at depth beneath North Algeria, ductile flow of lower continental crust (whatever its mineralogy is) induced by diffuse decoupling is a mechanism prone to explain the peculiar present-day geometry of the crustal neck. If this was the case, the variations in the crustal neck geometry along the margin may be partly due to heat flow variations: the volcanism onland associated with slab breakoff shows a decreasing age toward the extremities of the margin that is proposed to be related to slab tear propagation (Chazot et 
al., 2017 and references therein). Lower-crustal flow may have been concomitantly triggered and progressively facilitated toward the extremities of the margin, being at a maximum in the Kabylies area where volcanism, and thus slab breakoff, initiated.

\section{Conclusion}

The structure of the central part of the Algerian margin and basin is revealed by modeling and interpretation of land-sea combined wide-angle and reflection seismic profiles acquired across the Greater Kabylia region during the SPIRAL French-Algerian program. These results complement those published on the other sectors of the Algerian margin by Leprêtre et al. (2013), Mihoubi et al. (2014), Badji et al. (2015) and Bouyahiaoui et al. (2015).

The crust underlying the Algerian basin off Greater Kabylia is of oceanic affinity, like the crust imaged on all the SPIRAL profiles distributed along the margin. The oceanic crust in the Algerian basin is thinner $(4-5.5 \mathrm{~km})$ than the $7 \mathrm{~km}$ average value for typical oceanic crust and displays a two-layer structure that can be interpreted as representing layer 2 and layer 3.

Some differences in the seismic structure of the oceanic crust strengthen the hypothesis of two distinct sub-basins, the $\mathrm{EAB}$ and the $\mathrm{WAB}$, as earlier proposed from the magnetic pattern. This variability between the WAB and the EAB supports two different modes of emplacement with a 2-step evolution model for the WAB based on the seismic structure and magnetic pattern of the oceanic crust. In the Hannibal region, the atypical 3-layer structure of the oceanic crust is much likely the result of stacking of lava flows and volcaniclastic and/or hyaloclastic products over a thin crust similar to that bordering the margin. This structure is interpreted as resulting from Miocene post-accretion magmatism, which we suggest to be the offshore equivalent of the post-collisional magmatism known onland in Greater Kabylia. It rules out the hypothesis of the Hannibal High to be a N-S trending 
accretion center as proposed by Mauffret et al. (2004). Our results suggest that oceanic crust accretion occurred during a first southward back-arc opening stage and that this young oceanic basement was magmatically, and probably tectonically, reworked during a second, westward, back-arc opening stage that has shaped the WAB. In the same way than the onland magmatism, post-accretion volcanism would result into partial melting in the mantle metasomatised during the first opening stage, likely triggered by delamination and breakoff of the Tethyan slab under the margin (Chazot et al., 2017).

The sharp transition between the thinned continental and oceanic crusts suggests that the continental mantle was not exhumed in the crustal breakup zone before the onset of oceanic accretion. Alternatively, the 2-step evolution proposed for the WAB may have changed the initial geometry of the OCT by transcurrent movements during the second, westward, backarc opening.

Finally, the structure of the central Algerian margin offshore Greater Kabylia is that of a narrow $(\sim 70 \mathrm{~km})$, magma-poor rifted margin, with a wider zone of deep thinned continental crust than on the other segments of the Algerian margin. The Plio-Quaternary inversion of the margin related to ongoing convergence between the Africa and Eurasia plate is expressed by (1) a blind thrust system under the margin which goes toward the surface at the slope toe, and (2) an isostatic disequilibrium that can be the result of opposite flexures of two plates decoupled at the continental slope (Hamai et al., 2015). This isostatic disequilibrium and the related vertical movements are likely responsible for the peculiar asymmetrical shape of the crustal neck that may thus be a characteristic feature of inverted rifted margins.

Acknowledgements: The SPIRAL (Sismique Profonde et Investigations Régionales en Algérie) project is a collaboration between (1) Algerian scientific institutions: CRAAG 
(Centre de Recherche en Astronomie, Astrophysique et Géophysique), Sonatrach, and DGRST (Directorate-General for Scientific Research and Technological Development), and (2) French Research organizations: CNRS (Centre National de la Recherche Scientifique), Ifremer (Institut Français de Recherche pour l'Exploitation de la Mer), IRD (Institut de Recherche pour le Développement), and the Universities of Brest and Nice. We thank L. Geoffroy (UBO) for fruitful discussions upon the seismic facies interpretation in the Hannibal High region, Yahia Mohammedi (CRAAG) for the help in simplification of the geological map, and the crew of R/V L'Atalante and the complete SPIRAL scientific Team to help making the SPIRAL Project a success. The GMT (Wessel and Smith, 1995) and Seismic Unix (Stockwell, 1999; Stockwell and Cohen, 2003) software packages were used in the preparation of this paper. We would like to thank Guillermo Booth Rea, an anonymous reviewer and the editor Rob Govers whose helpful and constructive comments allowed improve the quality of the manuscript.

\section{References}

Abbassene, F., Chazot, G., Bellon, H., Bruguier, O., Ouabadi, A., Maury, R., Déverchère, J, Bosch, D., Monié, P., 2016. A 17 Ma onset for the post-collisional K-rich calcalkaline magmatism in the Maghrebides: Evidences from Bougaroun (northeastern Algeria) and geodynamic implications. Tectonophysics 674, 114-134, doi:10.1016/j.tecto.2016.02.013.

Afilhado, A., Moulin, M., Aslanian, D., Schnurle, P., Klingelhoefer, F., Nouzé, H., Rabineau, M., Leroux, E., Beslier, M.-O., 2015. Deep crustal structure across a young passive margin from wide-angle and reflection seismic data (The SARDINIA Experiment) - II. Sardinia’s margin. Bull. Soc. géol. France 186(4-5), 331-351. Aïte, M.O., Gélard, J.-P., 1997. Post-collisional palaeostresses in the Central Maghrebides 
(Great Kabylia, Algeria). Bull. Soc. géol. France 168(4), 423-436.

Asfirane, F., Galdeano, A., 1995. The aeromagnetic map of northern Algeria: Processing and interpretation. Earth Planet. Sci. Lett. 136, 61-78.

Auzende, J.-M., Bonnin, J., Olivet, J.-L., 1972. Compressive structure of Northern Algeria. Deep Sea Res., 19(2), 149-155.

Auzende, J.-M., Bonnin, J., Olivet, J.-L., 1973. The origin of the western Mediterranean basin. J. Geol. Soc. 129, 607-620.

Avedik, F., Renard, V., Allenou, J.P., Morvan, B., 1993. "Single bubble” air-gun array for deep exploration. Geophysics 58, 366-382.

Badji, R., Charvis, P., Bracene, R., Galvé, A., Badsi, M., Ribodetti, A., Benaissa, Z., Klingelhoefer, F., Medaouri, M., Beslier, M.-O., 2015. Geophysical evidence for a transform margin offshore Western Algeria: a witness of a subduction-transform edge propagator? Geophys. J. Int. 200, 1027-1043, doi:10.1093/gji/ggu454.

Belanteur, O., Bellon, H., Maury, R.C., Ouabadi, A., Coutelle, A., Semroud, B., Megartsi, M., Fourcade, S., 1995. Geology, geochemistry and 40K/40Ar geochronometry of Miocene magmatism in Algiers area, C.R. Acad. Sci. Paris, Ser. IIa, 321, 489-496.

Beslier, M., Aidi, C., Yelles-Chaouche, A., Ribodetti, A., Bracene, R., Schenini, L., Djellit, H., Sage, F., Deverchere, J., Medaouri, M., Klingelhoefer, F., Abtout, A., Charvis, P., Bounif, A., 2013. Tectonic inversion of the Algerian continental margin off Great Kabylia (North Algeria) - Insights from new MCS data (SPIRAL cruise). American Geophysical Union, Fall Meeting, San Francisco, 9-13 december, abstract \#T21A2522.

Biari, Y., Klingelhoefer, F., Sahabi, M., Aslanian, D., Schnurle, P., Berglar, K., ..., Benabdellouahed, M., 2015. Deep crustal structure of the North-West African margin from combined wide-angle and reflection seismic data (MIRROR seismic survey). Tectonophysics 656, 154-174. 
Billi, A., Faccenna, C., Bellier, O., Minelli, L., Neri, G., Piromallo, C., Presti, D., Scrocca, D., Serpelloni, E., 2011. Recent tectonic reorganization of the Nubia-Eurasia convergent boundary heading for the closure of the western Mediterranean. Bull. Soc. géol. France 182(4), 279-303.

Boillot, G., Féraud, G., Recq, M., Girardeau, J., 1989. Undercrusting by serpentinite beneath rifted margins. Nature 341, 523-525.

Booth-Rea, G., Ranero, C., Martínez-Martínez, J. M., Grevemeyer, I. 2007. Crustal types and Tertiary tectonic evolution of the Alborán sea, western Mediterranean. G-Cubed, 8, Q10004, doi: 10010. 11029/12007GC001661.

Bossière, G., Peucat, J.-L., 1985, New geochronological information by Rb-Sr and U-Pb investigations from the pre-Alpine basement of Grande Kabylie (Algeria). Can. J. Earth Sci. 22, 675-685.

Bouillin, J.-P., 1986. Le bassin maghrébin: Une ancienne limite entre l'Europe et l'Afrique à l'ouest des Alpes. Bull. Soc. Geol. France 8(4), 547-558.

Bouillin, J.-P., 1992. La répartition des affleurements de la Dorsale kabyle: héritage d'une segmentation mésozoïque de la marge nord-téthysienne? CR Acad. Sci., Paris 315, Série 2, 1127-1132.

Bouillin, J.-P., Durand-Delga, M., Gélard, J.-P., Leikine, M., Raoult, J.-F., Raymond, D., Tefiani, M., Vila, J.-M., 1973. Les olistostromes d'âge miocène inférieur liés aux flyschs allochtones kabyles de l'orogène alpin d'Algérie. Bull. Soc. géol. France XV(3-4), 340-344.

Bouillin, J.-P., Kornprobst, J., 1974. Associations ultrabasiques de Petite Kabylie: péridotites de type alpin et complexe stratifié; comparaison avec les zones internes bético-rifaines. Bull. Soc. géol. France XVI(1), 183-194.

Bouillin, J.-P., Durand-Delga, M., Olivier, P., 1986. Betic Rifian and Tyrrhenian Arcs: 
Distinctive features, genesis and development stages. In: The origin of arcs, F.

Wezel ed., Elsevier, New York, 281-304.

Bounif, A., Dorbath, C., Ayadi, A., Meghraoui, M., Beldjoudi, H., Laouami, N., Frogneux, M., Slimani, A., Alasset, P.J., Kharroubi, A., Ousadou, F., Chikh, M., Harbi, A., Larbes, S., Maouche, S., 2004. The 21 May 2003 Zemmouri (Algeria) earthquake Mw 6.8: Relocation and aftershock sequence analysis. Geophys. Res. Letters, 31, L19606, doi:10.1029/2004GL020586.

Bouyahiaoui, B., Sage, F., Abtout, A., Klingelhoefer, F., Yelles-Chaouche, K., Schnürle, P., Marok, A., Déverchère, J., Arab, M., Galve, A., Collot, J.Y., 2015. Crustal structure of the eastern Algerian continental margin and adjacent deep basin: implications for late Cenozoic geodynamic evolution of the western Mediterranean. Geophys. J. Int. 201, 1912-1938.

Bown, J.W., White, R.S., 1994. Variation with spreading rate of oceanic crustal thickness and geochemistry. Earth Planet. Sci. Lett. 121(3-4), 435-449.

Bracene, R., Patriat, M., Ellouz, N., Gaulier, J.-M., 2003. Subsidence history in basins of northern Algeria. Sedimentary Geology 156, 213-239.

Bruguier, O., Hammor, D., Bosch, D., Caby, R., 2009. Miocene incorporation of peridotite into the Hercynian basement of the Maghrebides (Edough massif, NE Algeria) : Implications for the geodynamic evolution of the Western Mediterranean. Chem. Geol. 261, 172-184.

Caby, R., Hammor, D., Delor, C., 2001. Metamorphic evolution, partial melting and Miocene exhumation of lower crust in the Edough metamorphic core complex, west Mediterranean orogen, eastern Algeria. Tectonophysics 342, 239-273.

Camerlenghi, A., Accettella, D., Costa, S., Lastras, G., Acosta, J., Canals, M., Wardell, N., 2008. Morphogenesis of the SW Balearic continental slope and adjacent abyssal plain, Western Mediterranean Sea. Int. J. Earth Sci. 98(4), 735-750. 
Cannat, M., 1996. How thick is the magmatic crust at slow spreading oceanic ridges. J. Geophys. Res. 101, 2847-2857.

Cannat, M., Manatschal, G., Sauter, D., Péron-Pinvidic, G., 2009. Assessing the conditions of continental breakup at magma-poor rifted margins: What can we learn from slow spreading mid-oceans ridges? CR Geoscience 341, 406-427.

Carlson, R.L., Herrick, C.N., 1990. Densities and porosities in the oceanic crust and their variations with depth and age. J. Geophys. Res. 95(B6), 9153-9170.

Carminati, E., Wortel, M.J.R., Spakman, W., Sabadini, R., 1998a. The role of slab detachment processes in the opening of the western-central Mediterranean basins: some geological and geophysical evidence. Earth Planet Sci. Lett. 160, 651-665.

Carminati, E., Wortel, M.J.R., Meijer, P.T., Sabadini, R., 1998b. The two-stage opening of the western-central Mediterranean basins: a forward modeling test to a new evolutionary model. Earth Planet. Sci. Lett. 160, 667-679.

Chazot, G., Abbassene, F., Maury, R.C., Déverchère, J., Bellon, H., Ouabadi, A., Bosch, D. 2017. An overview on the origin of post-collisional Miocene magmatism in the Kabylies (Northern Algeria): Evidence for crustal stacking, delamination and slab detachment. Journal of African Earth Sciences, 125, 27-41.

Chian, D., Louden, K.E., Minshull, T.A., Whitmarsh, R.B., 1999. Deep structure of the ocean-continent transition in the southern Iberia Abyssal Plain from seismic refraction profiles: Ocean Drilling Program (Legs 149 and 173) transect. J. Geophys. Res. 104(B4), 7443-7462.

Christensen, N.I., 1966. Elasticity of ultrabasic rocks. J. Geophys. Res. 71(24), 5921-5931. Christensen, N.I., Mooney, W.D., 1995. Seismic velocity structure and composition of the continental crust : a global view. J. Geophys. Res. 100(B7), 9761-9788.

Cohen, C.R., 1980. Plate tectonic model for the Oligo-Miocene evolution of the Western Mediterranean. Tectonophysics, 68, 283-311. 
Contrucci, I., Nercessian, A., Béthoux, N., Mauffret, A., Pascal, G., 2001. A Ligurian (Western Mediterranean Sea) geophysical transect revisited. Geophys. J. Int. 146(1), 74-97.

Contrucci, I., Klingelhöfer, F., Perrot, J., Bartolome, R., Gutscher, M. A., Sahabi, M., Rehault, J.-P., 2004. The crustal structure of the NW Moroccan continental margin from wide-angle and reflection seismic data. Geophys. J. Int. 159(1), 117-128.

Cope, M.J., 2003. Algerian licensing round may offer opportunity for exploration plays in deep offshore frontier. First break 21, 37-42.

Crawford, W.C., Hildebrand, J.A., Dorman, L.M., Webb, S.C., Wiens, D.A., 2003. Tonga Ridge and Lau basin crustal structure from seismic refraction data. J. Geophys. Res.: Solid Earth 108(B4), 2195, doi:10.1029/2001JB001435.

Dean, S.M., Minshull, T.A., Whitmarsh, R.B., Louden, K.E., 2000. Deep structure of the ocean-continent transition in the southern Iberia Abyssal Plain from seismic refraction profiles: The IAM-9 transect at $40^{\circ} 20^{\prime} \mathrm{N}$. J. Geophys. Res. 105(B3), 58595885.

Delescluse, M., Funck, T., Dehler, S.A., Louden, K.E., Watremez, L., 2015. The oceanic crustal structure at the extinct, slow to ultraslow Labrador Sea spreading center. J. Geophys. Res. Solid Earth, 120(7), 5249-5272, doi: 10.1002/2014JB011739.

Delouis, B., Vallée, M., Meghraoui, M., Calais, E., Maouche, S., Lammali, K., Mahsas, A., Briole, P., Benhamouda, F., Yelles, K., 2004. Slip distribution of the 2003 Boumerdes-Zemmouri earthquake, Algeria, from teleseismic, GPS, and coastal uplift data. Geophys. Res. Lett. 31, L18607, doi: 10.1029/2004GL020687.

Dessa, J.-X., Simon, S., Lelièvre, M., Beslier, M.-O., Deschamps, A., Béthoux, N., Solarino, S., Sage, F., Eva, E., Ferretti, G., Bellier, O., Eva, C., 2011. The GROSMarin experiment : three dimensional crustal structure of the North Ligurian margin from refraction tomography and preliminary analysis of microseismic 
measurements. Bull. Soc. géol. France 182(4), 305-321.

Déverchère, J., Yelles, K., Domzig, A., Mercier de Lépinay, B., Bouillin, J., Gaullier, V., Bracène, R., Calais, E., Savoye, B., Kherroubi, A., Le Roy, P., Pauc, H., Dan, G., 2005. Active thrust faulting offshore Boumerdes, Algeria, and its relations to the 2003 Mw 6.9 earthquake. Geophys. Res. Letters 32(4), L04311, doi:10.1029/2004GL021646.

Domzig, A., 2006. Déformation active et récente, et structuration tectonosédimentaire de la marge sous-marine algérienne. PhD Thesis, Université Bretagne Occidentale, 332 pp.

Domzig, A., Yelles, K., Le Roy, C., Déverchère, J., Bouillin, J.-P., Bracène, R., Mercier de Lépinay, B., Le Roy, P., Calais, E., Kherroubi, A., Gaullier, V., Savoye, B., Pauc, H., 2006. Searching for the Africa-Eurasia Miocene boundary offshore western Algeria (MARADJA'03 cruise). CR Geoscience 338, 80-91.

Durand Delga, M., 1969, Mise au point sur la structure du Nord-Est de la Grande Kabylie, Publ. Serv. Carte géol. Algérie, 39, 89-131.

Durand Delga, M., Fontboté, J.-M., 1980. Le cadre structural de la Méditerranée occidentale, Mem. BRGM 115, Orléans, 67-85.

Faccenna, C., Piromallo, C., Crespo-Blanc, A., Jolivet, L. Rossetti, F., 2004. Lateral slab deformation and the origin of the western Mediterranean arcs. Tectonics 23, TC1012, doi:10.1029/2002TC001488.

Fichtner, A., Villaseñor, A, 2015. Crust and upper mantle of the Western Mediterranean Constraints from full-waveform inversion. Earth Planet. Sci. Lett. 428, 52-62.

Francis, T.J.G., 1981. Serpentinization faults and their role in the tectonic of slow spreading ridge. J. Geophys. Res. 86, 11 616-11 622.

Frizon de Lamotte, D., Saint Bezar, B., Bracène, R., Mercier, E., 2000. The two main steps of the Atlas building and geodynamics of the western Mediterranean. Tectonics 
19(4), 740-761.

Frizon de Lamotte, D., Raulin, C., Mouchot, N., Wrobel- Daveau, J.-C., Blanpied, C., Ringenbach, J.-C., 2011. The southernmost margin of the Tethys realm during the Mesozoic and Cenozoic: Initial geometry and timing of the inversion processes. Tectonics 30, TC3002, doi:10.1029/2010TC002691.

Funck, T., Dickmann, T., Rihm, R., Krastel, S., Lykke-Andersen, H., Schmincke, H.-U., 1996. Reflection seismic investigations in the volcaniclastic apron of Gran Canaria and implications for its volcanic evolution. Geophys. J. Int. 125, 519-536.

Funck, T., Jackson, H.R., Louden, K.E., Dehler, S.A., Wu, Y., 2004. Crustal structure of the northern Nova Scotia rifted continental margin (eastern Canada). J. Geophys. Res.: Solid Earth, 109(B9), doi: 10.1029/2004JB003008.

Gailler, A., Klingelhoefer, F., Olivet, J. L. \& Aslanian, D., 2009. Crustal structure of a young margin pair: New results across the Liguro-Provencal basin from wide-angle seismic tomography. Earth Planet. Sci. Lett. 286 (1-2), 333-345.

Galdeano, A., Rossignol, J.-C., 1977. Assemblage à altitude constante des cartes d'anomalies magnétiques couvrant l'ensemble du bassin occidental de la Méditerranée. Bull. Soc. géol. France XIX(3), 461-468.

Gelabert, B., Sàbat, F., Rodríguez-Perea, A., 2002. A new proposal for the late Cenozoic geodynamic evolution of the western Mediterranean. Terra Nova 14 (2), 93-100.

Géry, B., Feinberg, H., Lorenz, C., Magné, J., 1981. Définition d'une série type de «l'Oligomiocene Kabyle» anté-nappes dans le Djebel Aissa-Mimoun (grande Kabylie, Algérie). CR Acad. Sci. Paris 292, 1529-1532.

Govers, R., Wortel, M.J.R., 2005. Lithosphere tearing at STEP faults: response to edges of subduction zones. Earth Planet. Sci. Lett. 236, 505-523.

Grevemeyer, I., Weigel, W., Dehghani, G.A., Whitmarsh, R.B., Avedik, F., 1997. The Aegir Rift: crustal structure of an extinct spreading axis. Mar. Geophys. Res. 19(1), 
Grevemeyer, I., Ranero, C. R., Leuchters, W., Pesquer, D., Booth-Rea, G., Gallart, J., 2011. Seismic constraints on the nature of crust in the Algerian-Balearic basin implications for lithospheric construction at back-arc spreading centres. American Geophysical Union, Fall Meeting, San Fransisco, abstract \#T53D-04.

Gueguen, E., Doglioni, C., Fernandez, M., 1998. On the post-25 Ma geodynamic evolution of the western Mediterranean. Tectonophysics 298 (1-3), 259-269.

Hamai, L., Petit, C., Abtout, A., Yelles-Chaouche, A., Déverchère, J., 2015. Flexural behaviour of the north Algerian margin and tectonic implications. Geophys. J. Int. 201, 1426-1436.

Hinz, K., 1973. Crustal structure of the Balearic sea. Tectonophysics 20(1-4), 295-302.

Hirata, N., Karp, B. Y., Yamaguchi, T., Kanazawa, T., Suyehiro, K., Kasahara, J., Kinoshita, H., 1992. Oceanic crust in the Japan basin of the Japan Sea by the 1990 Japan-USSR Expedition. Geophys. Res. Lett., 19(20), 2027-2030.

Hopper, J.R., Buck, W.R., 1998. Styles of extensional decoupling. Geology, 26, 699-702.

Horen, H., Zamora, M., Dubuisson, G., 1996. Seismic waves velocities and anisotropy in serpentinized peridotites from Xigaze ophiolite: Abundance of serpentine in slow spreading ridge. Geophys. Res. Lett. 23 (1), 9-12.

Hsü, K.J., Montadert, L., Shipboard Scientific Party, 1978. Initial Report of the Deep Sea Drilling Project, vol. 42, part 1, US Government Printing Office, Washington, DC, doi:10.2973:dsdp_proc.42-1.1978.

Jokat, W., Ritzmann, O., Schmidt-Aursch, M.C., Drachev, S., Gauger, S., Snow, J., 2003. Geophysical evidence for reduced melt production on the Arctic ultraslow Gakkel mid-ocean ridge. Nature 423, 962-965.

Jokat, W., Schmidt-Aursch, M.C., 2007. Geophysical characteristics of the ultraslow spreading Gakkel Ridge, Arctic Ocean. Geophys. J. Int. 168, 983-998. 
Jerram, D.A., Single, R.T., Hobbs, R.W., Nelson, C.E., 2009. Understanding the offshore flood basalt sequence using onshore vocanic facies analogues: an example from the Faroe-Shetland basin. Geol. Mag. 146(3), 353-367.

Jolivet, L., Faccenna, C., 2000. Mediterranean extension and the Africa-Eurasia collision. Tectonics 19(6), 1095-1106.

Kherroubi, A., Déverchère, J., Yelles, A., Mercier de Lépinay, B., Domzig, A., Cattaneo, A., Bracène, R., Gaullier, V., Graindorge, D., 2009. Recent and active deformation pattern off the easternmost Algerian margin, Western Mediterranean Sea: New evidence for contractional tectonic reactivation. Marine Geology 261, 17-32.

Klingelhöfer, F., Géli, L., Matias, L., Steinsland, N., Mohr, J., 2000a. Crustal structure of a super-slow spreading centre: A seismic refraction study of Mohns Ridge, $72^{\circ} \mathrm{N}$. Geophys. J. Int. 141, 509-526, doi:10.1046/j.1365-246x.2000.00098.x.

Klingelhöfer, F., Géli, L., White, R.S., 2000b. Geophysical and geochemical constraints on crustal accretion at the very-slow spreading Mohns Ridge. Geophys. Res. Letters 27(10), 1547-1550.

Klingelhoefer, F., Edwards, R.A., Hobbs, R.W., England, R.W., 2005. Crustal structure of the NE Rockall Trough from wide-angle seismic data modeling. J. Geophys. Res: Solid Earth, 110(B11), doi: 10.1029/2005JB003763.

Klingelhoefer, F., Biari, Y., Sahabi, M., Aslanian, D., Schnabel, M., Matias, L., ..., Austin, J. A., 2016. Crustal structure variations along the NW-African continental margin: A comparison of new and existing models from wide-angle and reflection seismic data. Tectonophysics 674, 227-252.

Leprêtre, A., Klingelhoefer, F., Graindorge, D., Schnurle, P., Beslier, M.-O., Yelles, K., Déverchère, J., Bracene, R., 2013. Multiphased tectonic evolution of the Central Algerian margin from combined wide-angle and reflection seismic data off Tipaza, Algeria. J. Geophys. Res. 118, 3899-3916, doi:10.1002/jgrb.50318. 
Lonergan, L., White, N., 1997. Origin of the Betic-Rif mountain belt. Tectonics 16, 504522.

Louden, K. E. (1980). The crustal and lithospheric thicknesses of the Philippine Sea as compared to the Pacific. Earth Planet. Sci. Lett. 50(1), 275-288.

Ludwig, W.J., Nafe, J.E., Drake, C.L., 1970. Seismic refraction. The Sea 4, 53-84.

Malinverno, A., Ryan, W.B.F., 1986. Extension in the Tyrrhenian Sea and shortening in the Apennines as result of arc migration driven by sinking of the lithosphere. Tectonics $5,227-245$.

Mauffret, A., 2007. The Northwestern (Maghreb) boundary of the Nubia (Africa) Plate. Tectonophysics 429(1-2), 21-44.

Mauffret, A., El-Robrini, M., Gennesseaux, M., 1987. Indice de la compression récente en mer Méditerranée: un basin losangique sur la marge nord-algérienne. Bull. Soc. géol. Fr. 3, 1195-1206.

Mauffret, A., Frizon de Lamotte, D., Lallemant, S., Gorini, C., Maillard, A., 2004. E-W opening of the Algerian basin (Western Mediterranean). Terra Nova 16(5), 257-264.

Maury, R.C., Fourcade, S., Coulon, C., El Azzouzi, M., Bellon, H., Coutelle, A., Ouabadi, A., Semroud, B., Megartsi, M., Cotton, J., Belanteur, O., Louni-Hacini, A., Piqué, A., Capdevila, R., Hernandez, J., Réhault, J.-P., 2000. Post-collisional Neogene magmatism of the Mediterranean Maghreb margin: a consequence of slab breakoff. C.R. Acad. Sci. Paris 331, 159-173.

Mihoubi, A., Schnürle, P., Benaissa, Z., Badsi, M., Bracene, R., Djelit, H., Geli, L., Sage, F., Agoudjil, A., Klingelhoefer, F., 2014. Seismic imaging of the eastern Algerian margin off Jijel: integrating wide-angle seismic modelling and multichannel seismic pre-stack depth migration. Geophys. J. Int. 198, 1486-1503.

Minshull, T.A., Muller, M.R., Robinson, C.J., White, R.S., Bickle, M.J., 1998. Is the oceanic Moho a serpentinization front?. In : Mills, R.A. \& Harrison, K. (Eds), 
Modern Ocean Floor Processes and the Geological Record, Geol. Soc. Spec. Publ., London 148, 71-80.

Moulin, M., Klingelhoefer, F., Afilhado, A., Aslanian, D., Schnurle, P., Nouzé, H., Rabineau, M., Beslier, M.-O., Feld, A., 2015. Deep crustal structure across a young passive margin from wide-angle and reflection seismic data (The SARDINIA Experiment) - I. Gulf of Lion’s margin. Bull. Soc. géol. France 186(4-5), 309-330. Muller, M.R., Robinson, C.J., Minshull, T.A., White, R.S., Bickle, M.J., 1997. Thin crust beneath ocean drilling program borehole 735B at the southwest Indian Ridge?, Earth Planet. Sci. Lett. 148, 93-107.

Mutter, C. Z., Mutter, J. C., 1993. Variations in thickness of layer 3 dominate oceanic crustal structure. Earth Planet. Sci. Lett. 117(1), 295-317.

Nocquet, J.-M., Calais, E., 2004. Geodetic measurements of crustal deformation in the Western Mediterranean and Europe. Pure Appl. Geophys. 161(3), 661-681.

Pascal, G. P., Mauffret, A., Patriat, P., 1993. The ocean-continent boundary in the Gulf of Lion from analysis of expanding spread profiles and gravity modelling. Geophys. J. Int. 113(3), 701-726.

Pepe, F., Sulli, A., Bertotti, G., Cella, F., 2010. Architecture and Neogene to recent evolution of the Western Calabrian continental margin: An upper plate perspective to the Ionian subduction system, Central Mediterranean. Tectonics 29, TC3007, doi:10.1029/2009TC002599.

Pesquer, D.A., Grevemeyer, I., Ranero, C.R., and Gallart, J., 2008. Seismic structure of the passive continental margin of SE Spain and the SW Balearic promontory, Western Mediterranean Sea, Eos Trans. AGU, 89(53), Fall Meet. Suppl., Abstract T43C2053.

Planke, S., Alvestad, E., Eldholm, O., 1999. Seismic characteristics of basaltic extrusive and intrusive rocks. The Leading Edge, doi:10.1190/1.1438289. 
Planke, S., Symonds, P.A., Alvestad, E., Skogseid, J., 2000. Seismic volcanostratigraphy of large-volume basaltic extrusive complexes on rifted margins. J. Geophys. Res. 105(B8), 19,335-19,351.

Prada, M., Sallarès, V., Ranero, C.R., Vendrell, M.G., Grevemeyer, I., Zitellini, N., de Franco, R., 2014. Seismic structure of the Central Tyrrhenian basin: Geophysical constraints on the nature of the main crustal domains. J. Geophys. Res. Solid Earth 119, 52-70, doi:10.1002/2013JB010527.

Purdy, G. M., Kong, L.S.L., Christeson, G.L., Solomon, S.C., 1992. Relationship between spreading rate and the seismic structure of midocean ridges. Nature 355(6363), 815817.

Raymond, D., 1976. Evolution sédimentaire et tectonique du nord-ouest de la Grande Kabylie (Algérie) au cours du cycle alpin, Ph. D. thesis, Univ. Pierre et Marie Curie, Paris, 160pp.

Réhault, J.-P., Boillot, G., Mauffret, A., 1984. The Western Mediterranean basin geological evolution. Marine Geology 55, 447-477.

Rosenbaum, G., Lister, G. S., Duboz, C., 2002. Reconstruction of the tectonic evolution of the western Mediterranean since the Oligocene. J. Virtual Expl. 8, 107-130.

Rosenbaum, G., Lister, G.S., 2004. Formation of arcuate orogenic belts in the western Mediterranean region. Geol. Soc. Am. Special Papers 383, 41-56.

Roure, F., Casero, P., Addoum, B., 2012. Alpine inversion of the North African margin and delamination of its continental lithosphere. Tectonics 31, TC3006, doi:10.1029/2011TC002989.

Sàbat, F., Roca, E., Muñoz, J., Vergés, J., Santanach, P., Sans, M., Masana, E., Estévez, A., Santisteban, C., 1995. Role of extension and compression in the evolution of the eastern margin of Iberia: the ESCI-València Trough seismic profile. Rev. Soc. Geol. España 8(4), 431-448. 
Saadallah, A., Caby, R., 1996. Alpine extensional detachment tectonics in the Grande Kabylie metamorphic core complex of the Maghrebides (northern Algeria). Tectonophysics 267, 257-273.

Sallarès, V., Martinez-Loriente, S., Prada, M., Gracia, E., Ranero, C., Gutscher, M.-A., Bartolome, R., Gailler, A., Danobeitia, J.J., Zitellini, N., 2013. Seismic evidence of exhumed mantle rock basement at the Gorringe Bank and the adjacent Horseshoe and Tagus abyssal plains (SW Iberia). Earth Planet. Sci. Lett. 365, 120-131.

Sclater, J. G., Karig, D., Lawver, L. A., Louden, K., 1976. Heat flow, depth, and crustal thickness of the marginal basins of the south Philippine Sea. J. Geophys. Res. 81(2), 309-318.

Schettino, A., Turco, E., 2006. Plate kinematics of the Western Mediterranean region during the Oligocene and Early Miocene. Geophys. J. Int. 166, 1398-1423.

Serpelloni, E., Vannucci, G., Pondrelli, S., Argnani, A., Casula, G., Anzidei, M., Baldi, P., Gasperini, P., 2007. Kinematics of the Western Africa-Eurasia plate boundary from focal mechanisms and GPS data. Geophys. J. Int. 169(3), 1180-1200, doi: 10.1111/j.1365-246X.2007.03367.x

Spakman, W., Wortel, R., 2004. A tomographic view on Western Mediterranean geodynamics, in: Cavazza, W., Roure, F., Spakman, W., Stampfli, G.M., Ziegler, P.A. (Eds.), The TRANSMED Atlas : The Mediterranean region from crust to mantle, Geological and geophysical framework of the Mediterranean and the surrounding areas. Springer Berlin Heidelberg, pp. 31-52.

Serpelloni, E., Vannucci, G., Pondrelli, S., Argnani, A., Casula, G., Anzidei, M., Baldi, P. Gasperini, P., 2007. Kinematics of the western Africa-Eurasia plate boundary from focal mechanisms and GPS data, Geophys. J. Int., 169(3), 1180-1200, doi:10.1111/j.1365-246X.2007.03367.x.,

Stockwell, J.W., 1999. The CWP/SU: seismic Un*x package. Computers \& Geosciences, 
25(4), 415-419.

Stockwell, J.W., Cohen, J.K., 2003. The CWP/SU: Seismic Unix Release 37: a free package for seismic research and processing. Center for Wave Phenomena, Colorado School of Mines.

Strzerzynski, P., Déverchère, J., Cattaneo, A., Domzig, A., Yelles, K., Mercier de Lepinay, B., Babonneau, N., Boudiaf, A., 2010. Tectonic inheritance and Pliocene-Pleistocene inversion of the Algerian margin around Algiers : Insights from multibeam and seismic reflection data. Tectonics 29, TC2008, doi:10.1029/2009TC002547.

Turner, I.M., Peirce, C., Sinha, M.C., 1999. Seismic imaging of the axial region of the Valu Fa Ridge, Lau basin - the accretionary processes of an intermediate back-arc spreading ridge. Geophys. J. Int. 138, 495-519.

Van Avendonk, H.J.A., Holbrook, W.S., Nunes, G.T., Shillington, D.J., Tucholke, B.E., Louden, K.E., Larsen, H.C., Hopper, J.R., 2006. Seismic velocity structure of the rifted margin of the eastern Grand Banks of Newfoundland, Canada. J. Geophys. Res. 111, B11404, doi:10.1029/2005JB004156.

van Hinsbergen, D.J.J., Vissers, R.L., Spakman, W., 2014. Origin and consequences of western Mediterranean subduction, rollback, and slab segmentation. Tectonics 33, 393-419, doi:10.1002/tect.20125.

Vergés, J., Sàbat, F., 1999. Constraints on the Neogene Mediterranean kinematic evolution along a $1000 \mathrm{~km}$ transect from Iberia to Africa. Geological Society, London, Sp. Publ. 156, 63-80.

Vergés, J., Fernàndez, M., 2012. Tethys-Atlantic interaction along the Iberia-Africa plate boundary: The Betic-Rif orogenic system. Tectonophysics 579, 144-172.

Vidal, N., Gallart, J., Dañobeitia, J., 1998. A deep seismic transect from the NE Iberian Peninsula to the western Mediterranean. J. Geophys. Res. 103(B6), 12381-12396. Wessel, P., Smith, W.H., 1995. New version of the generic mapping tools. Eos, Trans. Am. 
Geophys. Union 76(33), 329-329.

White, R.S., Westbrook, G.H., Bowen, A.N., Fowler, S.R., Spence, G.D., Prescott, C., Barton, P.J., Joppen, M., Morgan, J., Bott, M.H.P., 1987. Hatton bank (northwest U.K.) continental margin structure. Geophys. J. Int. 89(1), 265-272, doi: https://doi.org/10.1111/j.1365-246X.1987.tb04418.x

White, R.S., McKenzie, D.P., O’Nions, K., 1992. Oceanic crustal thickness from seismic measurements and rare earth elements inversions. J. Geophys. Res. 97(B13), 1968319715.

Wildi, W., 1983. La chaine tello-rifaine (Algérie, Maroc, Tunisie): Structure, stratigraphie et évolution du Trias au Miocène. Rev. Geol. Dyn. Geogr. Phys., 24, 201-297.

Yelles-Chaouche, A., Boudiaf, A., Djellit, H., Bracene, R., 2006. La tectonique active de la région nord-algérienne. CR Geoscience 338, 126-139.

Yelles, A., Domzig, A., Déverchère, J., Bracène, R., Mercier de Lépinay, B., Strzerzynski, P., Bertrand, G., Boudiaf, A., Winter, T., Kherroubi, A., Le Roy, P., Djellit, H., 2009. Plio-Quaternary reactivation of the Neogene margin off NW Algiers, Algeria: The Khayr al Din bank. Tectonophysics 475(1), 98-116.

Zelt, C.A., 1999. Modelling strategies and model assessment for wide-angle seismic traveltime data. Geophys. J. Int. 139, 183-204.

Zelt, C.A., Smith, R.B., 1992. Seismic traveltime inversion for 2-D crustal velocity structure, Geophys. J. Int., 108(1), 16-34.

Zelt, C.A., Barton, P.J., 1998. Three-dimensional seismic refraction tomography: A comparison of two methods applied to data from the Faeroe basin. J. Geophys. Res. $103,7187-7210$.

\section{Table}




\begin{tabular}{|l|l|l|l|l|}
\hline Phases & Name & Number of & Rms & Chisquare \\
\hline Water & & 2104 & 0.040 & 0.326 \\
\hline Refraction in the Plio-Quaternary & Ps1 & 1811 & 0.075 & 1.134 \\
\hline sedimentary layer & & & & \\
\hline Reflection at the top of the & PsP1 & 1270 & 0.101 & 2.066 \\
\hline Refraction in the upper crust & Pg1 & 3009 & 0.087 & 1.111 \\
\hline Reflection in the lower crust & PgP & 184 & 0.120 & 2.949 \\
\hline Refraction in the upper crust & Pg2 & 4627 & 0.080 & 1.115 \\
\hline Refraction in the upper mantle & Pn & 4716 & 0.092 & 1.541 \\
\hline Reflection at the Moho & PmP & 624 & 0.085 & 1.115 \\
\hline
\end{tabular}

Table 1. Residual traveltimes and chi-square errors for all phases, using forward modeling at the Greater Kabylia SPIRAL transect.

\section{Figure captions}

Figure 1. (A) Present day tectonic map of the Western Mediterranean area. Bathymetry and topography are from ETOPO1 1-minute Global relief (www.ngdc.noaa.gov). Major tectonic features are from Frizon de Lamotte et al. (2000) and Billi et al. (2011). The white arrow shows velocity of the African plate relative to the stable European plate $(\sim 5 \mathrm{~mm} / \mathrm{y})$ from GPS measurements (Nocquet and Calais, 2004). The red rectangle marks the location of the study area displayed in Figure 2. Thick white lines locate the 5 land-sea SPIRAL seismic profiles: from west to east, (Mo): Mostaganem, (Ti): Tipaza, (GK): Greater Kabylia, (Ji): Jijel, (An): Annaba. The dark blue circle locates the position of the Hannibal High. The internal zones are red shaded; BI: Balearic islands, GSZ: Gibraltar subduction zone. The 
three insets show the Western Mediterranean setting at $20 \mathrm{Ma}$ (inset a), $\sim 17 \mathrm{Ma}$ (inset b) and $5 \mathrm{Ma}$ (inset c) modified from Bouayahiaoui et al. (2015), illustrating the Internal Zones (Al: Alboran, Ka: Greater and Lesser Kabylia, Pe: Peloritan, Ca: Calabria) migration behind the Tethyan subduction front, and the associated back-arc opening of the Algerian basin. The kinematic reconstruction is from Medaouri et al. (2014) and Badji et al. (2015) for the West Algerian basin (WAB) and from Bouayahiaoui et al. (2015) for the East Algerian basin (EAB). C: Corsica, S: Sardinia, LPB: Liguro-Provençal basin, T: Tethys, Ty: Tyrrhenian Sea. (B) Synthetic geological cross-section through northern Algeria (along the GK profile on figure A), from Frizon de Lamotte et al. (2011) modified.

Figure 2. Location map of the land-sea deep seismic line EF-Spi11 across the north Algerian margin; red dots : OBS station, red triangles : land stations (unfilled symbols for stations that did not record the offshore shots), labels correspond to stations illustrated on Figures 3 and 4, red star: location of the 2003 Boumerdès earthquake from Bounif et al. (2004) and its focal solution from Harvard Global CMT, Bo: Boumerdès, Ti: Tigzirt, De: Dellys, TO: Tizi-Ouzou, Ta: Tazmalt. Simplified geological map onland (modified from Wildi, 1983); 1: Kabylian Oligo-Miocene, 2: Flysch nappe, 3: Basement (Paleozoic included), 4: Calc-alkaline magmatism, 5: Numidian nappes, 6: Trias and Jurasic limestones, 7: Tellian for-chain (Miocene), 8: Autochtonous formations, 9: Post-Miocene formations, 10: Tellian nappes, 11: Major anormal contact.

Figure 3. EXAMPLES OF REPRESENTATIVE WIDE-ANGLE RECORD SECTIONS ACQUIRED ALONG THE GREAT KABYLIA PROFILE AND SHOWING P-WAVE ARRIVALS. (A) Seismic data section of vertical channel of OBS 20 LOCATED WITHIN THE DEEP BASIN. (B) Seismic data section of vertical component of land station SP02 
LOCATED 7 KM SOUTH OF THE SHORELINE. See location of both stations on Figure 2. Data processing includes a bandpass filter, an offset-dependent gain and a $6 \mathrm{~km} / \mathrm{s}$ velocity reduction. The coloured lines and corresponding labels mark the picks of the first arrivals used for data modeling.

Figure 4. (A) Magnetic anomaly along the profile from the SPIRAL survey. (B) Final velocity model from forward modeling contoured at a $0.25 \mathrm{~km} / \mathrm{s}$ interval. OBS locations are indicated by red circles and landstations by red inverted triangles. Solid black lines represent interfaces from MCS coincident profile (see Figure 10). Shaded areas are constrained from seismic rays. IN THE BOTTOM PANELS, shaded grey area represents normal Atlantic-type oceanic crust from White et al. (1992), grey line extended continental crust from Christensen and Mooney (1995), green shaded areas exhumed mantle from Sallarès et al. (2013, dark green) and Dean et al. (2000, light green) and red lines velocity DEPTH PROFILES FROM THIS STUDY; (C) MEAN 1D VELOCITY PROFILE CALCULATED FROM INDIVIDUAL PROFILES EXTRACTED EVERY 10 KM FROM THE CRUST IN THE HANNIBAL REGION (DOMAIN 4); (D) 1D velocity profiles extracted every $10 \mathrm{~km}$ in the region of thin oceanic crust (Domain 3); the 2 profiles in purple are extracted in the southernmost part of Domain 3. (E) 1D velocity profiles extracted every $10 \mathrm{~km}$ in the region of extended continental crust (Domain 2). (F) Mean 1D velocity profile calculated from profiles extracted every $10 \mathrm{~km}$ from unthinned continental crust (Domain 1).

Figure 5. Forward modeling of the refracted and reflected arrivals performed for (A) OBS 01, (B) OBS 20, (C) OBS 26, (D) OBS 37 and (E) the land station SP02. The three panels for each station present (a) ray tracing through the P-wave velocity-depth model, (b) observed travel times picking 
(in red) and calculated travel times produced by ray tracing (in grey), and (c) picks of the first and second arrivals superimposed on the data. The stations are located on Figure 2.

Figure 6 . Ray coverage of the velocity model on a grid of $0.5 \times 0.5 \mathrm{~km}$ cell size.

Figure 7. Resolution parameter for all velocity nodes of the final velocity model. White and yellow areas $(>0.5)$ can be considered well resolved. OBS positions are indicated by red circles and landstations by red inverted triangles. BLUE CIRCLES MARK THE POSITION OF THE VELOCITY NODES.

Figure 8. Error analysis by model perturbation. (A) Results from simultaneous variation of the depth of the Moho and velocities in the lower crustal layer. Contours indicate the number of picks explained by the forward model. The uncertainties of the most important boundaries calculated from the $95 \%$ confidence limit of the f-test are given in the grey boxes. (B) Results from variation of the lower crustal velocities only. (C) Results from variation of the Moho depth. The uncertainties of the most important boundaries calculated from the $95 \%$ confidence limit of the f-test are given in the grey box.

Figure 9. Results from gravity modeling. Positions of OBSs (circles) and land stations (inverted triangles) are indicated. Italic numbers give densities used for gravity modeling in $\mathrm{g} / \mathrm{cm}^{3}$. Black line indicates layer boundaries from seismic modeling. (A) Shipboard measured free-air gravity anomaly (black line), and predicted anomaly from final model (red line). (B) Gravity model. 
Figure 10. (A) Time-migrated section of the Spi11 MCS line coincident with the marine part of the wide-angle data profile (location on Figure 2). Simplified interpretation: PQ : Plio-Quaternary ; UU : Messinian Upper Unit (green shaded) ; MU : Messinian mobile unit (yellow shaded) ; BMU : Base of the evaporitic Messinian series (light brown line) ; CU chaotic unit (light green shaded); Mio : pre-Messinian Miocene ; AB : acoustic basement; FRS: flat-ramp system; VH and VF (blue shaded): volcano-detritic and volcanic facies (see text for details). (B) Same as A with seismic velocities from the wide-angle forward modeling converted to two-way travel-time overlain. OBS locations are indicated by red circles. Same color code than on Figure 5 for the different domains, whose limits are deduced from the MCS interpretation (A) or from the velocity model (B). The close-ups of figures 11 and 12 are framed.

Figure 11. Time-migrated section of the Spi11 MCS line showing a seismic facies transition at the top of the acoustic basement that coincides with the change from continental to oceanic crust on the velocity model.

Figure 12. Time-migrated section of the Spi11 MCS line enlarged on the northern part of the line through the Hannibal region showing the seismic facies VF topped by a strong reflector (T) and $\mathrm{VH}$, interpreted as post-accretion volcanic formations (see interpreted line on Figure 10A and explanation in text). M: Moho.

Figure 13. 1D velocity profile extracted from the forward velocity model in Hannibal region (Domain 4) (dark blue line), and in the thin oceanic crust (Domain 3) (light blue line). The 
upward shift of the Hannibal 1D model by removing the uppermost high gradient layer (dotted dark blue line) gives a 1D profile similar to the one in the thin oceanic crust (see explanations in text). Shaded grey area as on Figure 5.

Figure 14. Comparison of 1D velocity profiles in the oceanic domain. Red line marks the Hannibal ridge area (Domain 4) without the uppermost crustal layer (see Figure 13), and blue line marks oceanic domain south of Hannibal (Domain 3). (A) Normal oceanic crust (White et al., 1992) ; (B) Mohns Ridge (Klingelhoefer et al., 2000a) ; (C) Mean velocity models in the Algerian basin, in the Tipaza sector of the WAB (in purple; Leprêtre et al., 2013; (Ti) on Fig. 1), and in the Jijel (in light green; Mihoubi et al., 2014; (Ji) on Fig. 1), and the Annaba (in dark green; Bouyahiaoui et al., 2015; (An) on Fig. 1) sectors of the EAB ; (D) Ligurian Sea (Contrucci et al., 2001); (E) Ocean-continent transition (OCT) in the Gulf of Lions (Moulin et al., 2015) ; (F) Oceanic domain in the Provençal basin (Afilhado et al., 2015; Moulin et al., 2015).

Figure 15. Comparison of the deep structure of three Western Mediterranean margins (lines $\mathrm{a}, \mathrm{b}$ and $\mathrm{c}, \mathrm{d}, \mathrm{e}$ ). The location of the 5 transects is indicated by red lines on the map. (A) the Algerian margin offshore Jijel (Mihoubi et al., 2015; (Ji) on Figure 1), (B) the Algerian margin offshore Tigzirt (this study), (C) the Algerian margin offshore Tipasa (Leprêtre et al., 2013; (Ti) on Figure 1), (D) and (E) the conjugate Gulf of Lions and West Sardinian margins (Afilhado et al., 2015; Moulin et al., 2015). CC: Continental Crust; OC: Oceanic Crust; OCT: Ocean-continent Transition.

Figure 16. Shaded-relief map of first vertical derivative of the continued, reduced-to-pole aeromagnetic data (data from Asfirane and Galdeano, 1995). RTP data were continued to a 
surface $4000 \mathrm{~m}$ above ground. The map shows the sub-circular cluster of magnetic anomalies associated with basement highs in the Hannibal region. Note that neither the cluster contour nor the inner anomalies depict a N-S linear trend. VH: VH seismic facies interpreted on the MCS SPI11 profile (see Figures 10, 12), which correlates with one of these anomalies. Thin grey lines locate the SPIRAL seismic profiles. The dotted white line locates the OCT in the study area. Thick dashed lines locate the trace of the Algerian segmented slab identified in the tomographic study of Fichtner and Villaseñor (2015). The pink dashed line locates the limit between the west (WAB) and the east (EAB) Algerian basins.

Figure 17. Results of the isostatic analysis and flexure modeling along the Greater Kabylia transect (modified from Hamai et al., 2015). (A) Density model calculated by converting the seismic velocities into densities. In the particular case of the Greater Kabylia transect, the lack of constraints on the Moho depth onland prevents the isostatic signal from evidencing the upward flexure of the continental plate. Blue line shows the geometry of the Moho corrected from the isostatic disequilibrium using the conversion 2 given by the blue line on (B)(see explanations in text and in Hamai et al., 2015). (B) 2-D flexural model; green and blue lines are the computed deflection corresponding to two different velocity-density conversions and black line is the modeled deflection. Dark vertical lines delimitate the decoupling zone between the north oceanic and the south continental flexed plates.

\section{Descriptive captions for supplementary material:}

Annexe.1: Seismic data section of vertical channel for 40 OBS stations acquired along the Great Kabylia profile. The data processing includes a bandpass filter, an offset-dependent gain and a $6 \mathrm{~km} / \mathrm{s}$ velocity reduction.

Annexe.2 Seismic data section of vertical channel for 40 OBS stations acquired along the 
Great Kabylia profile. The colored lines correspond to travel-time time picks of phases used for modeling (Red, orange, purple, dark blue, green, light orange, turquoise, yellow corresponds respectively to water, PsP1,PsP2,Ps1, Pg1,Pg2 Pmp, Pn) the solid dark blue line corresponds to the predicted arrivals times for each phase.

Annexe.3: Seismic data section of vertical channel for land stations acquired along the Great Kabylia profile. The data processing includes a bandpass filter, an offset-dependent gain and a $6 \mathrm{~km} / \mathrm{s}$ velocity reduction.

Annexe.4: Seismic data section of vertical channel for land stations acquired along the Great Kabylia profile. The data processing includes a bandpass filter, an offset-dependent gain and a $6 \mathrm{~km} / \mathrm{s}$ velocity reduction. The colored lines correspond to travel-time picks of phases used for modeling (light blue, dark blue and green correspond respectively for Pg1, Pg2 and Pn), the solid dark blue line corresponds to the predicted arrivals times for each phase. 
Highlights:

- Modeling of deep seismic data images the deep structure of the Algerian margin.

- The Algerian margin offshore Greater Kabylia is a narrow, magma-poor rifted margin.

- Margin inversion may trigger lower crust seaward flow due to isostatic disequilibrium.

- A 3-layer thin oceanic crust reveals post-accretion volcanism in the Algerian basin.

- A two-step Miocene evolution of the West Algerian back-arc basin is proposed. 

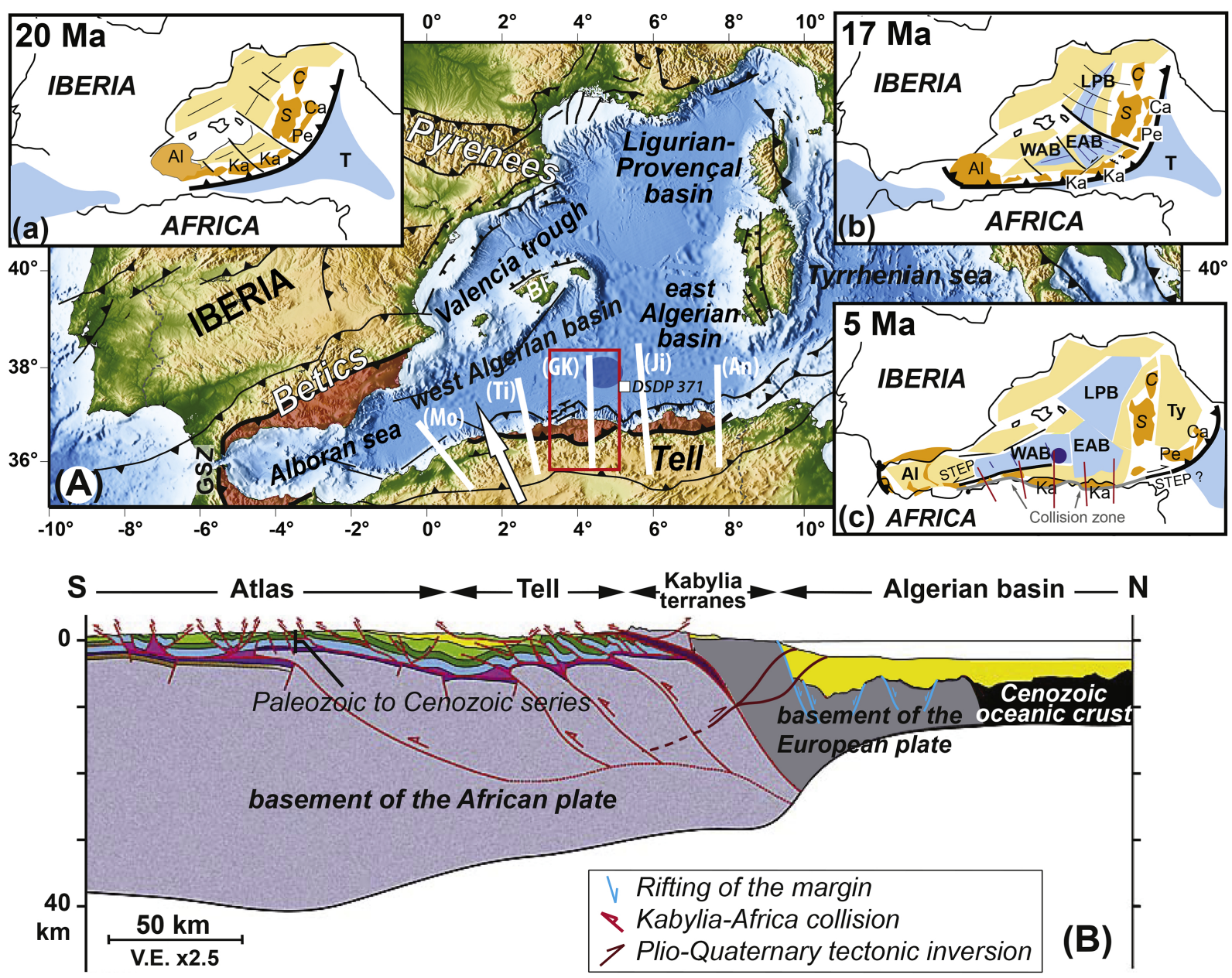

Figure 1 


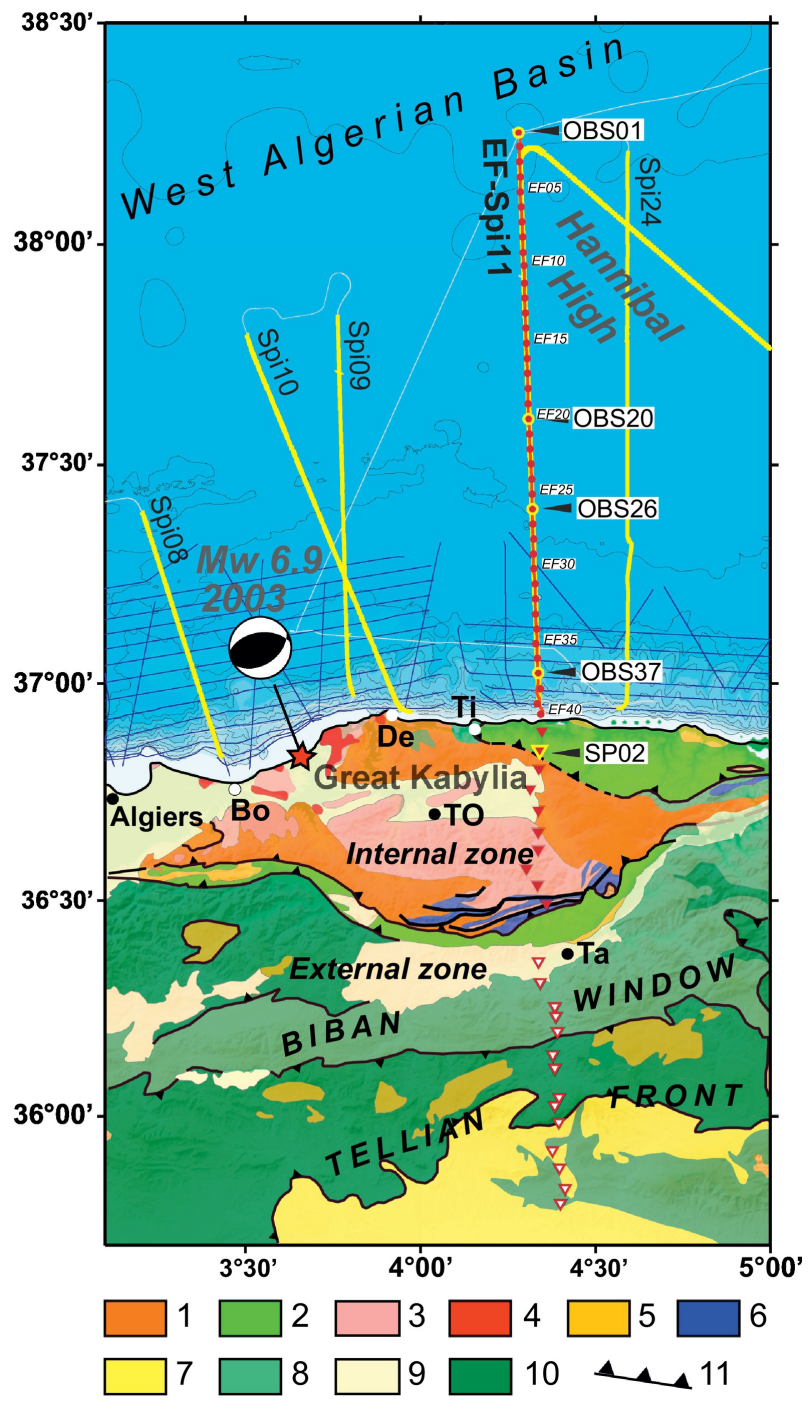

Figure 2 


\section{Offset [km]}
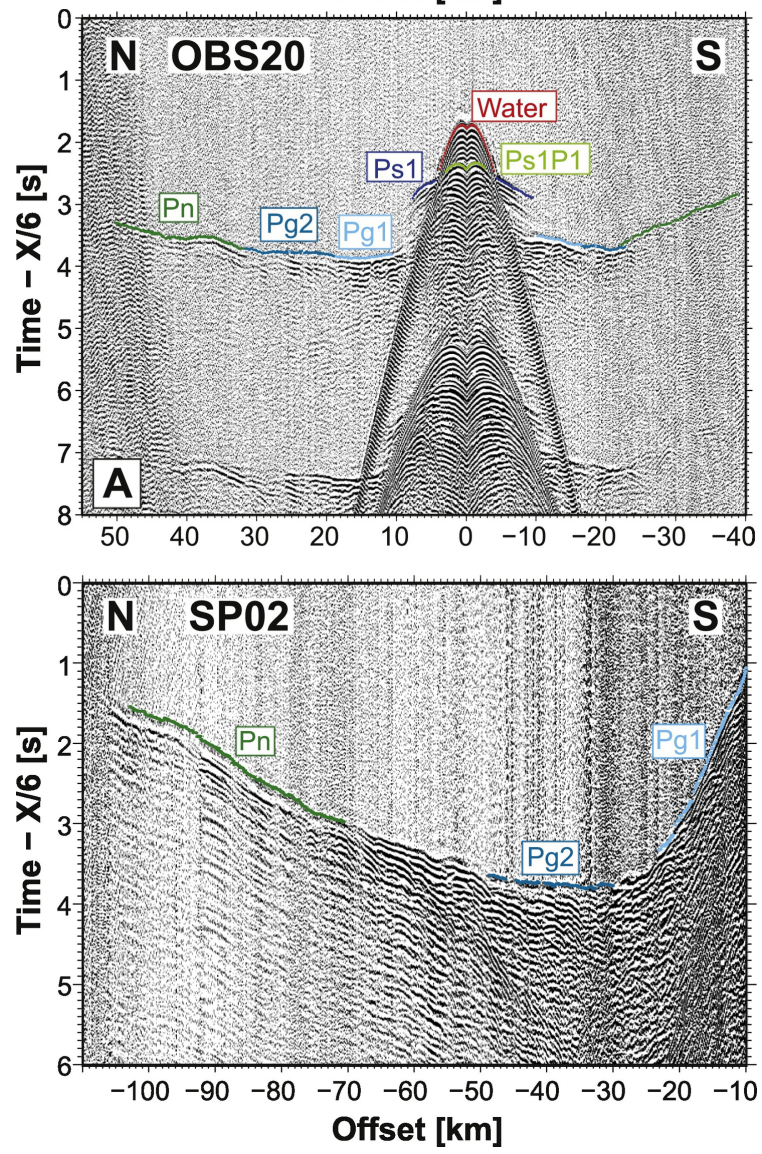

Figure 3 


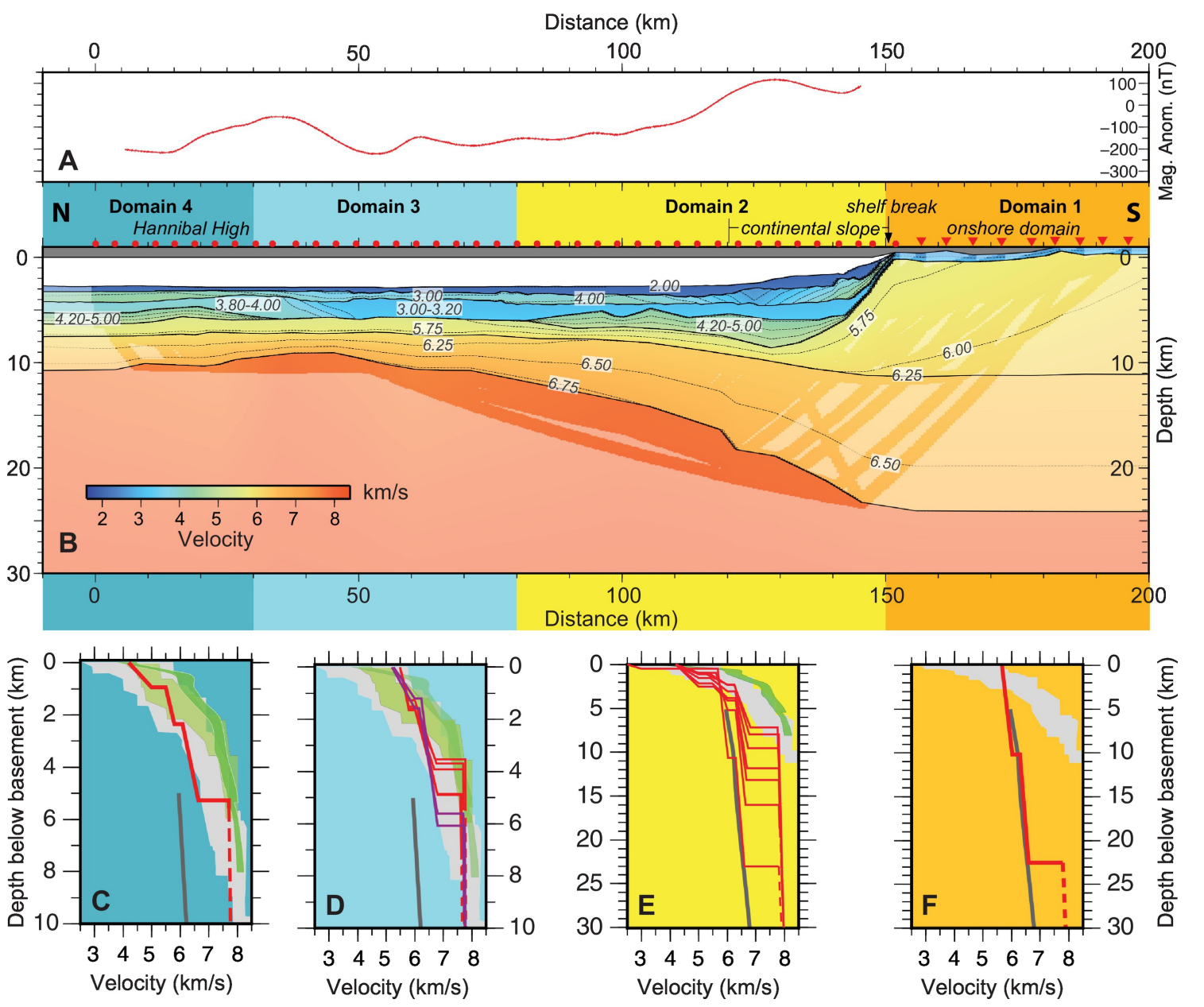

Figure 4 


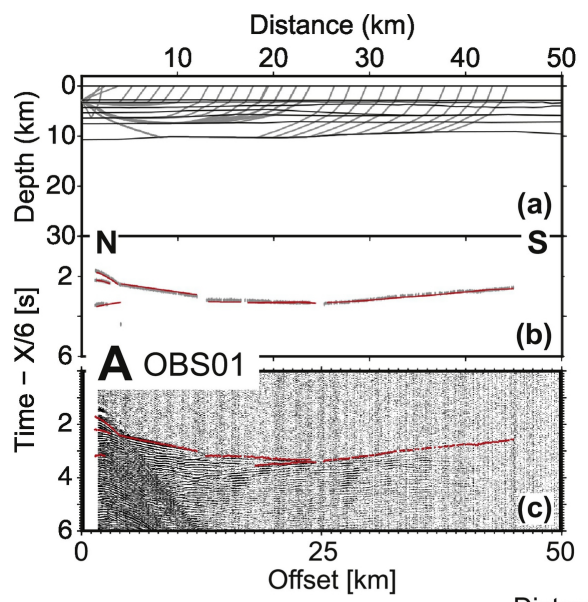

Distance $(\mathrm{km})$

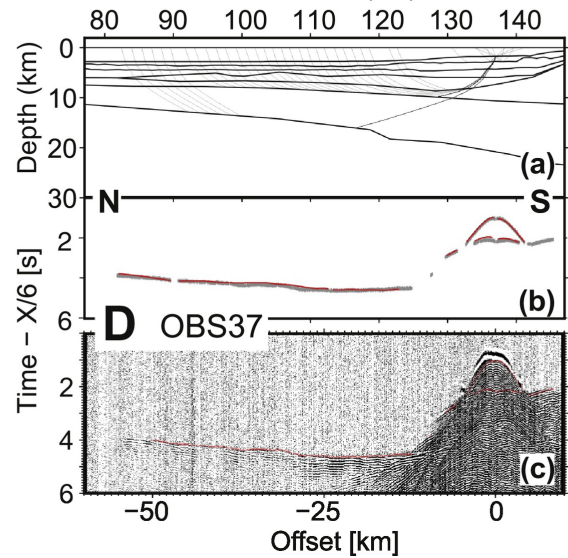

Distance (km)

100

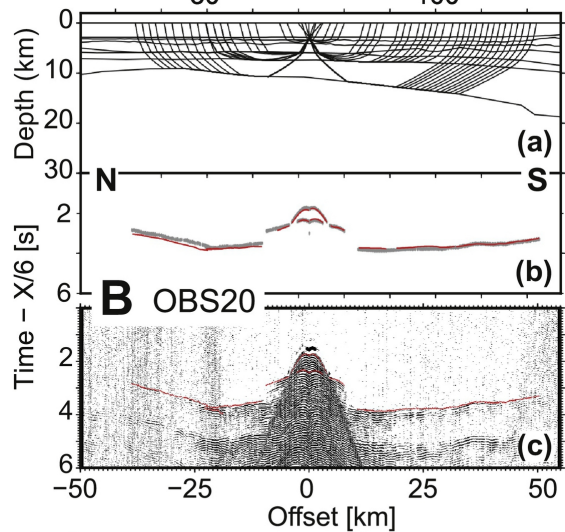

Distance (km)

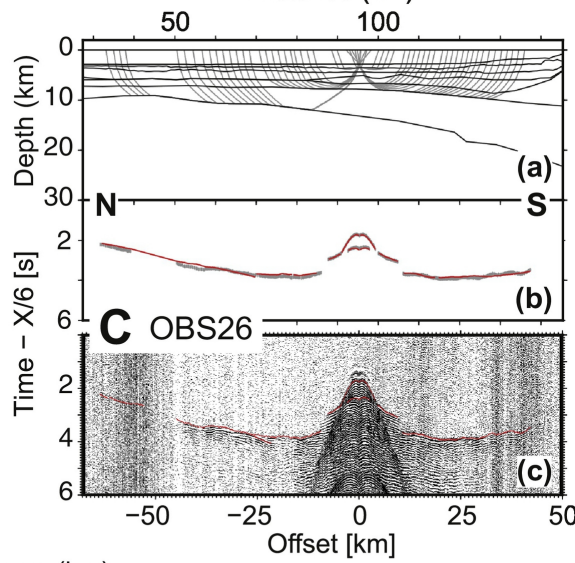

Distance (km)

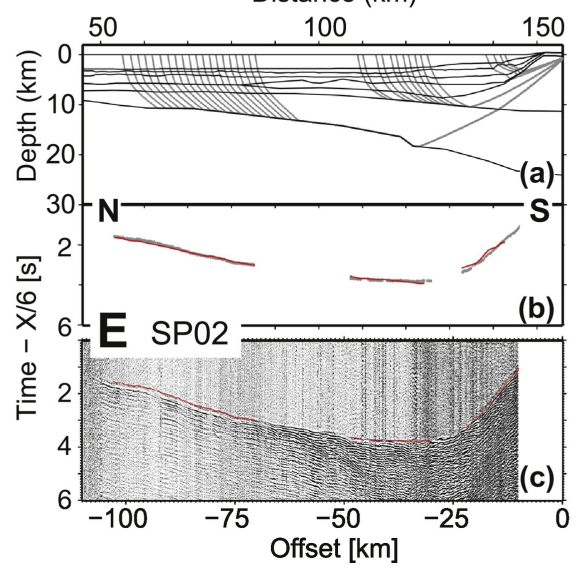

Figure 5 


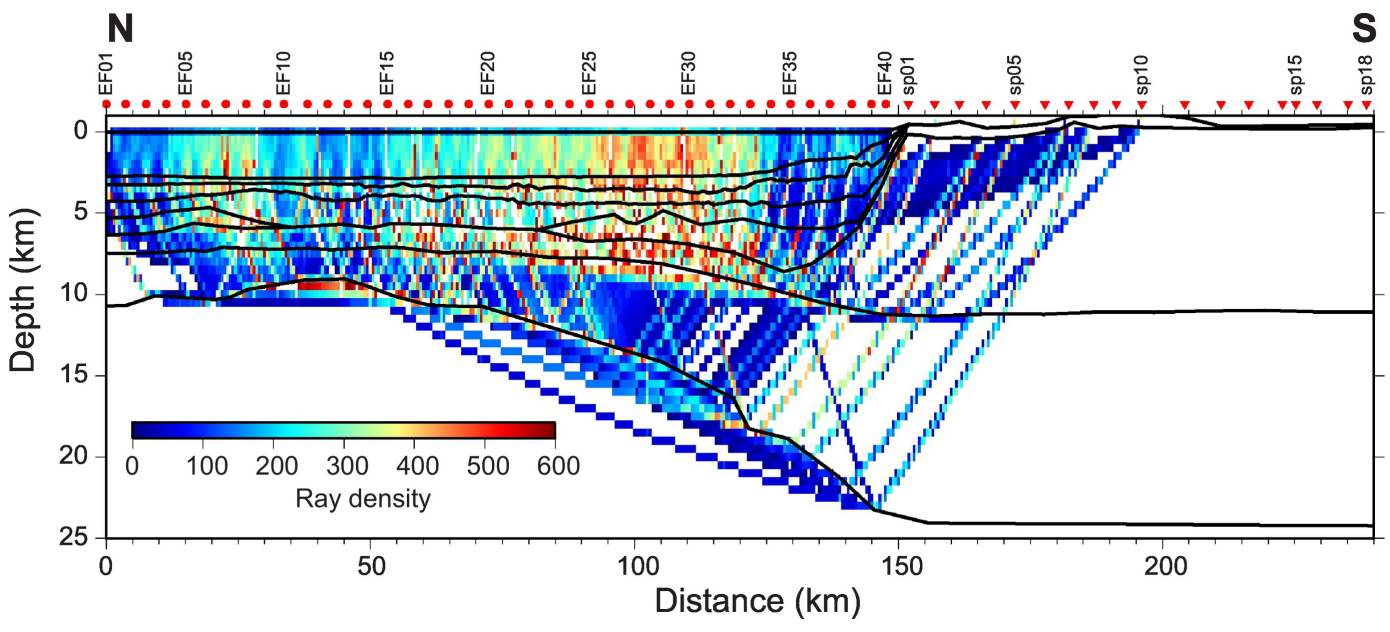

Figure 6 


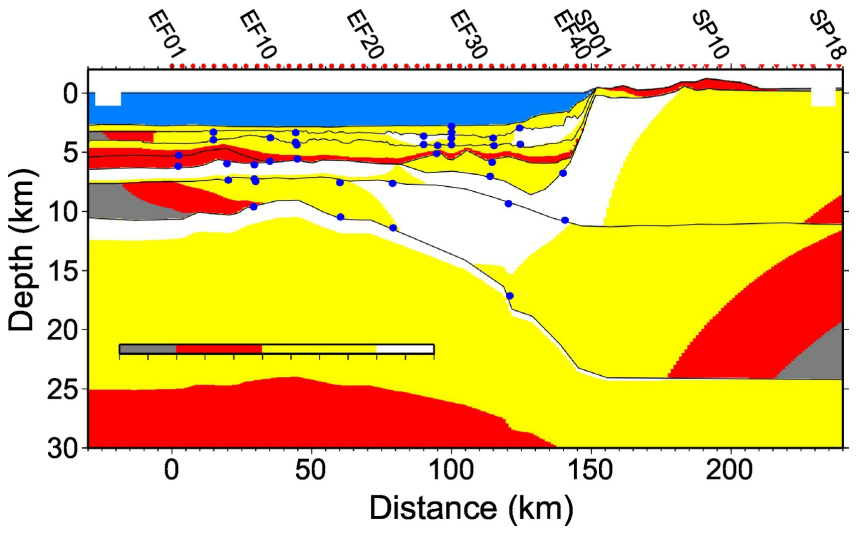

Figure 7 


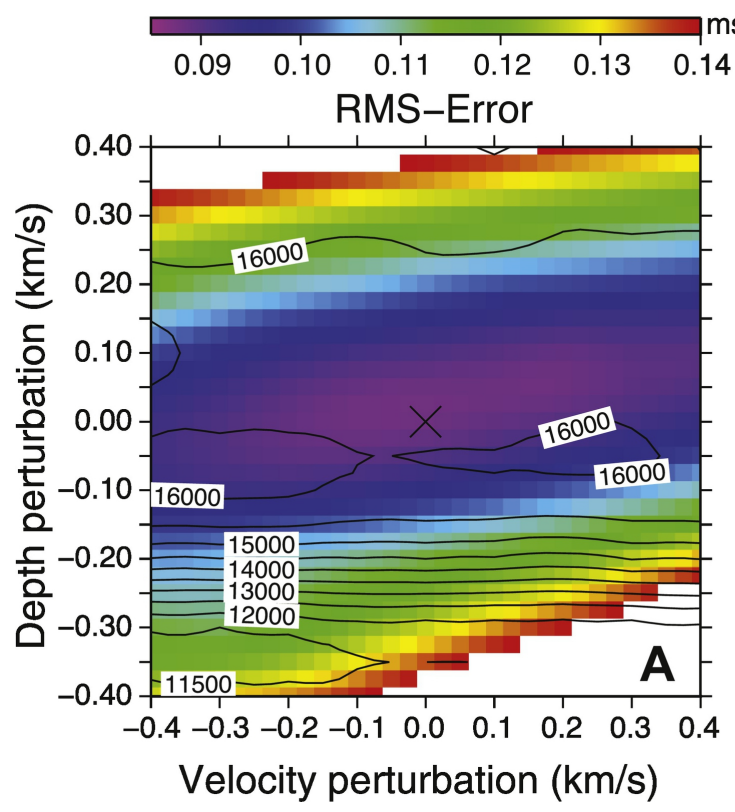

Velocity perturbation $(\mathrm{km} / \mathrm{s})$
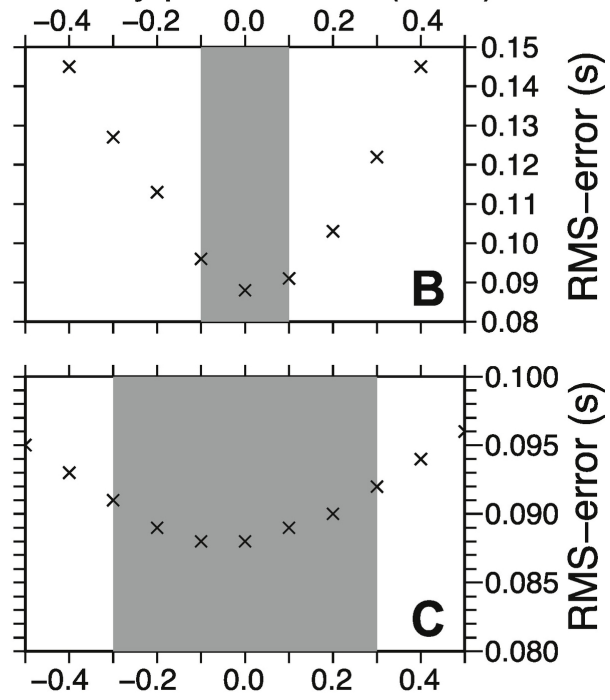

Depth perturbation $(\mathrm{km})$

Figure 8 


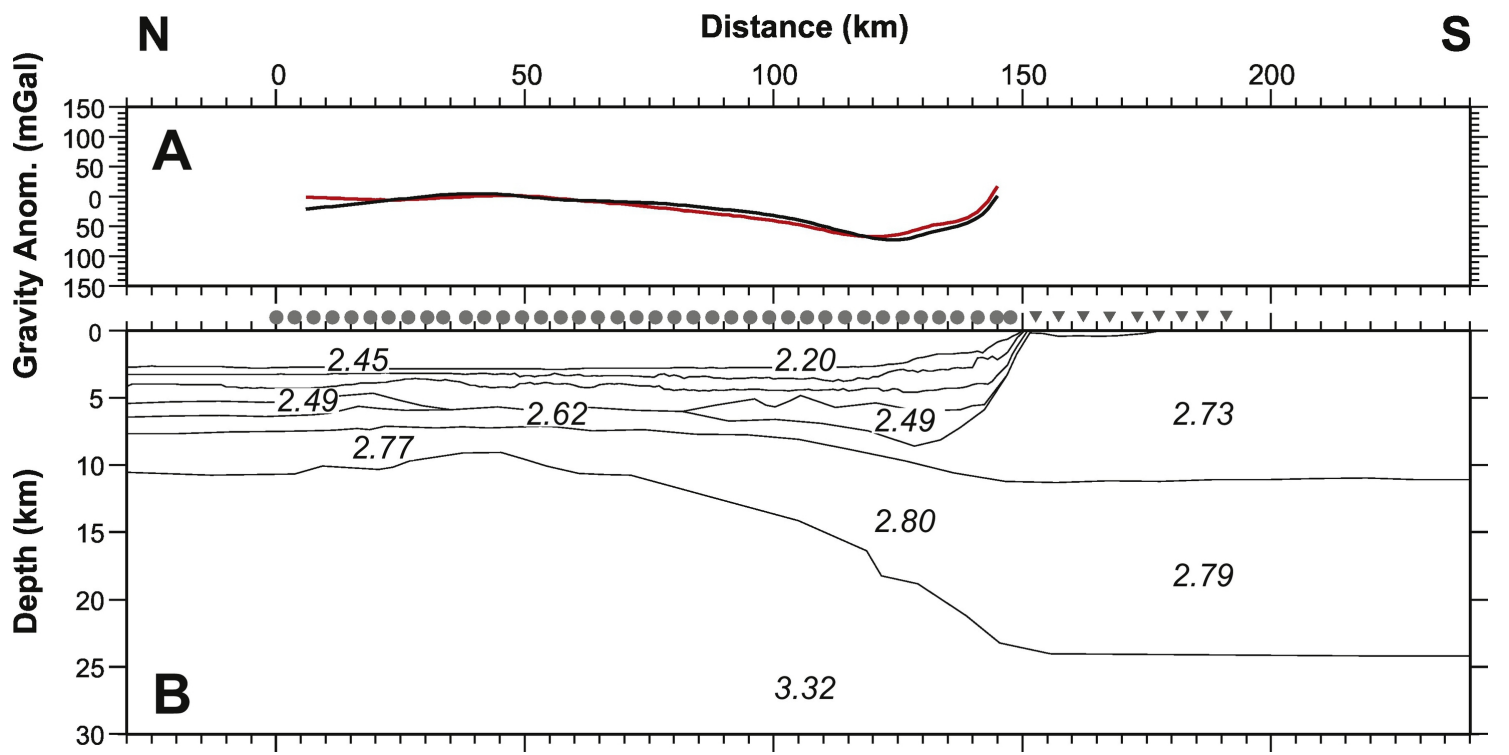

Figure 9 


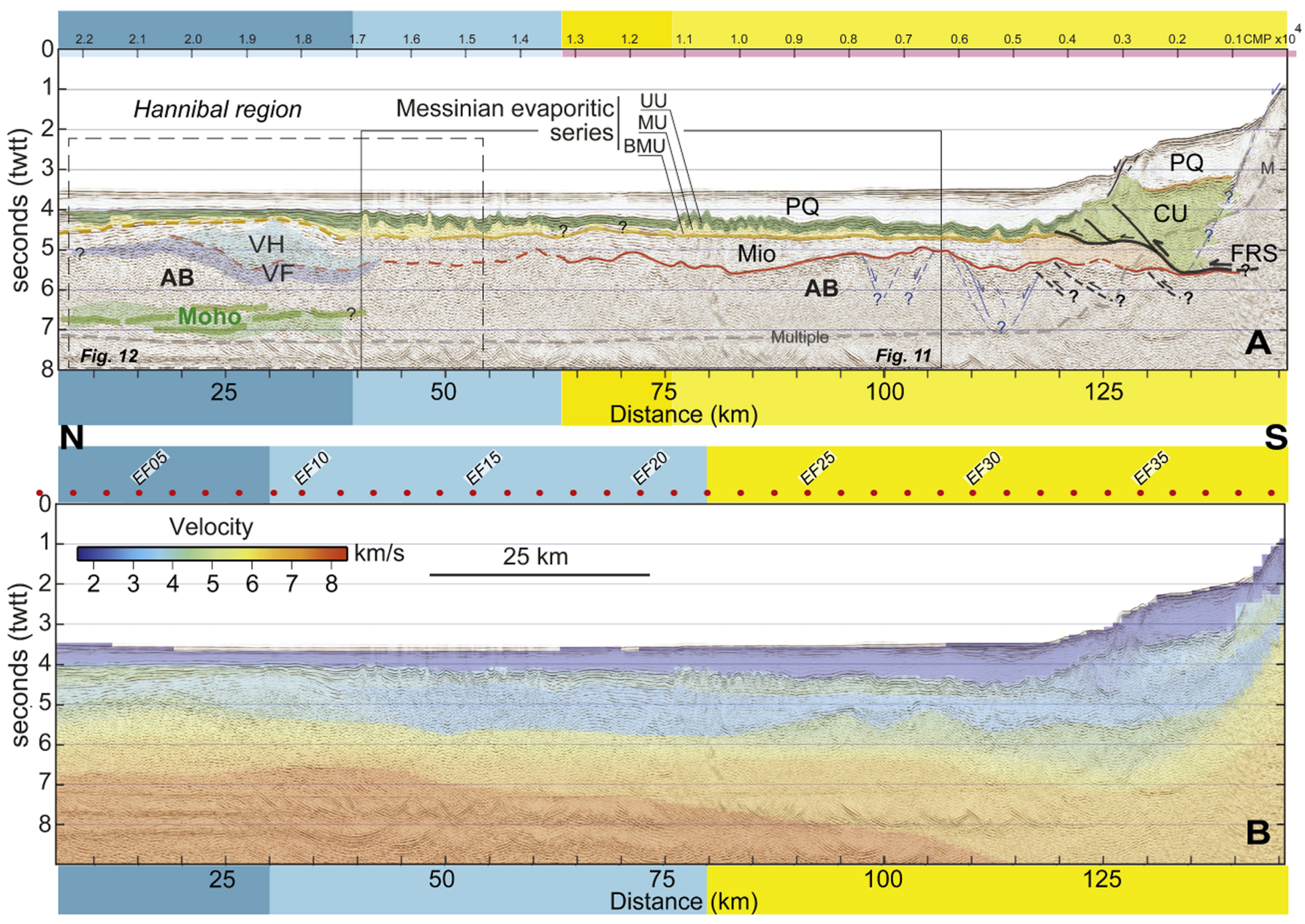




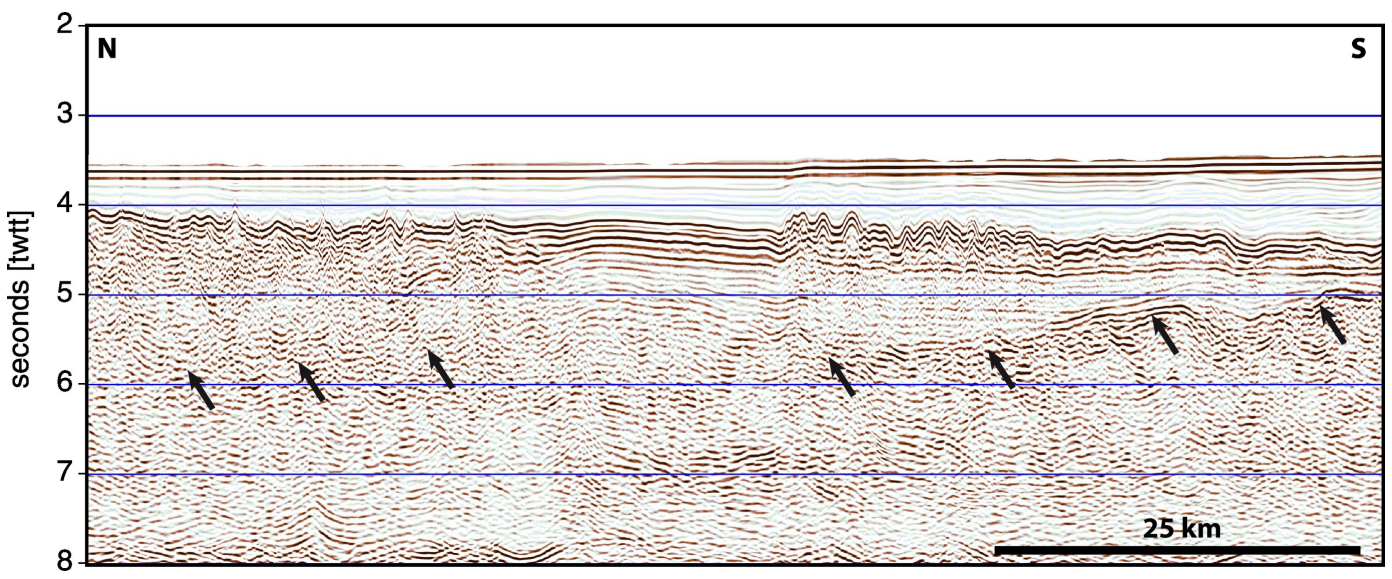

Figure 11 


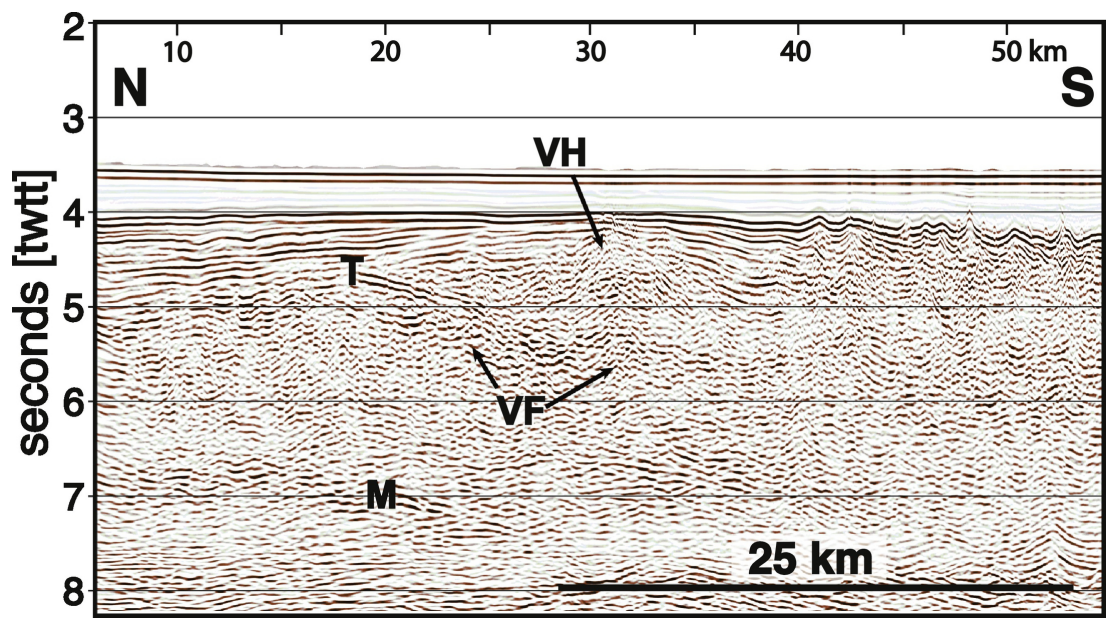

Figure 12 


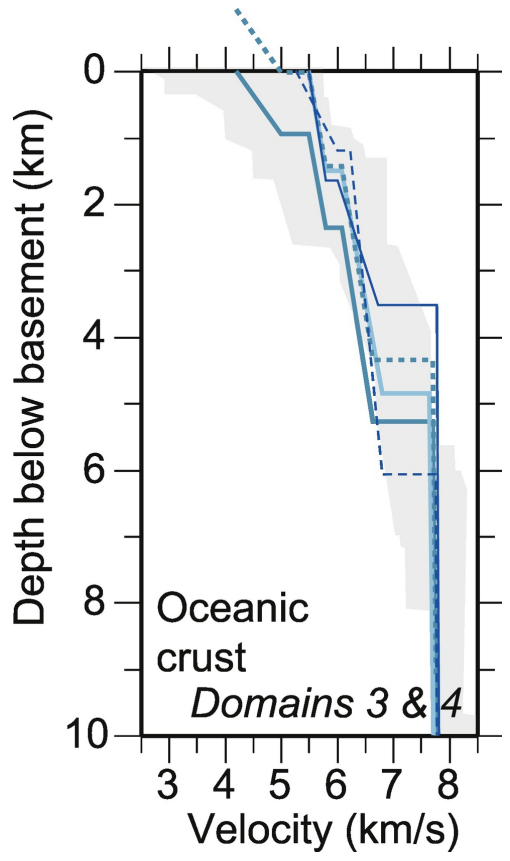

Figure 13 


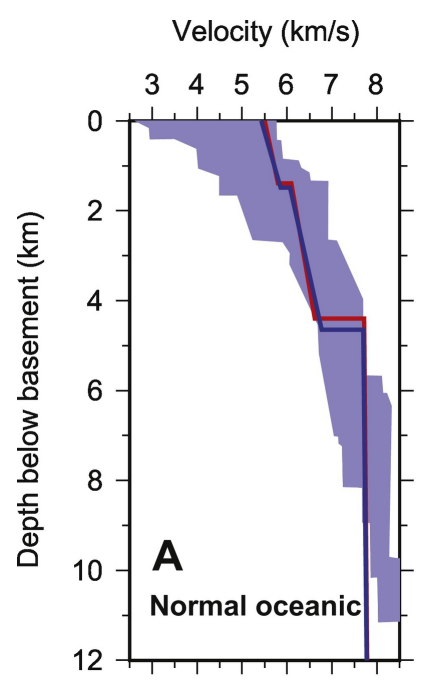

Velocity $(\mathrm{km} / \mathrm{s})$

Velocity $(\mathrm{km} / \mathrm{s})$
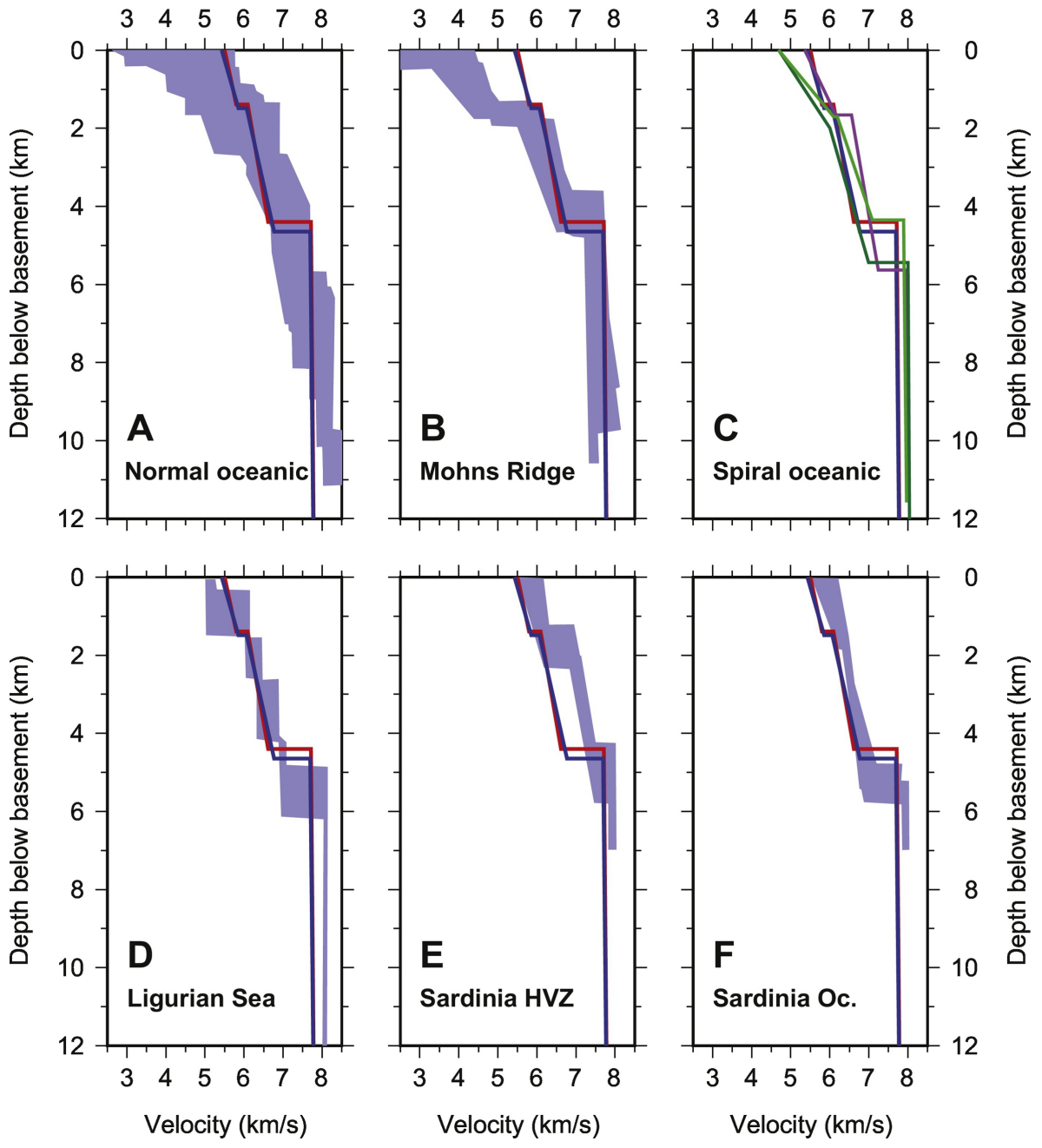

Figure 14 


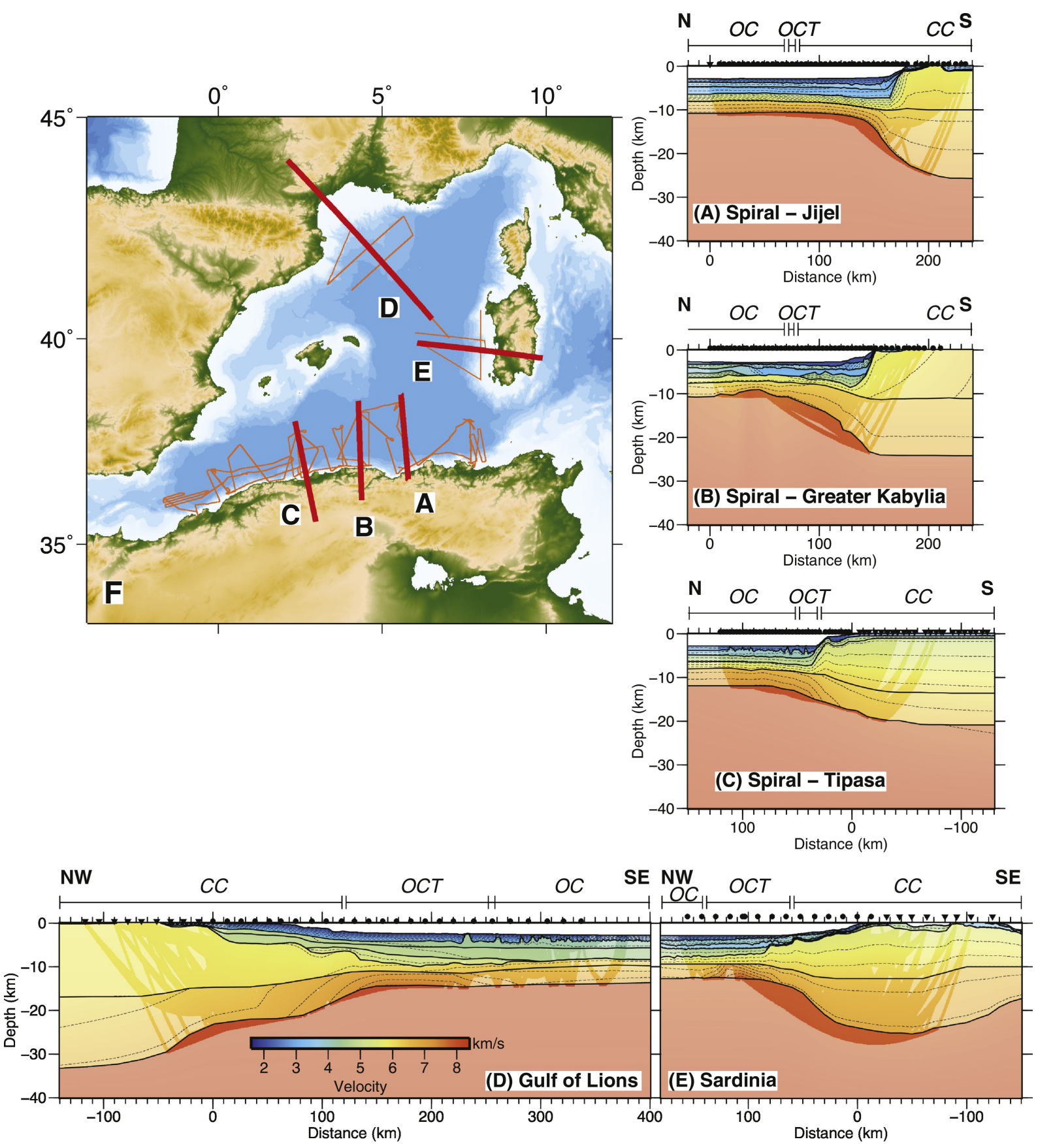

Figure 15 



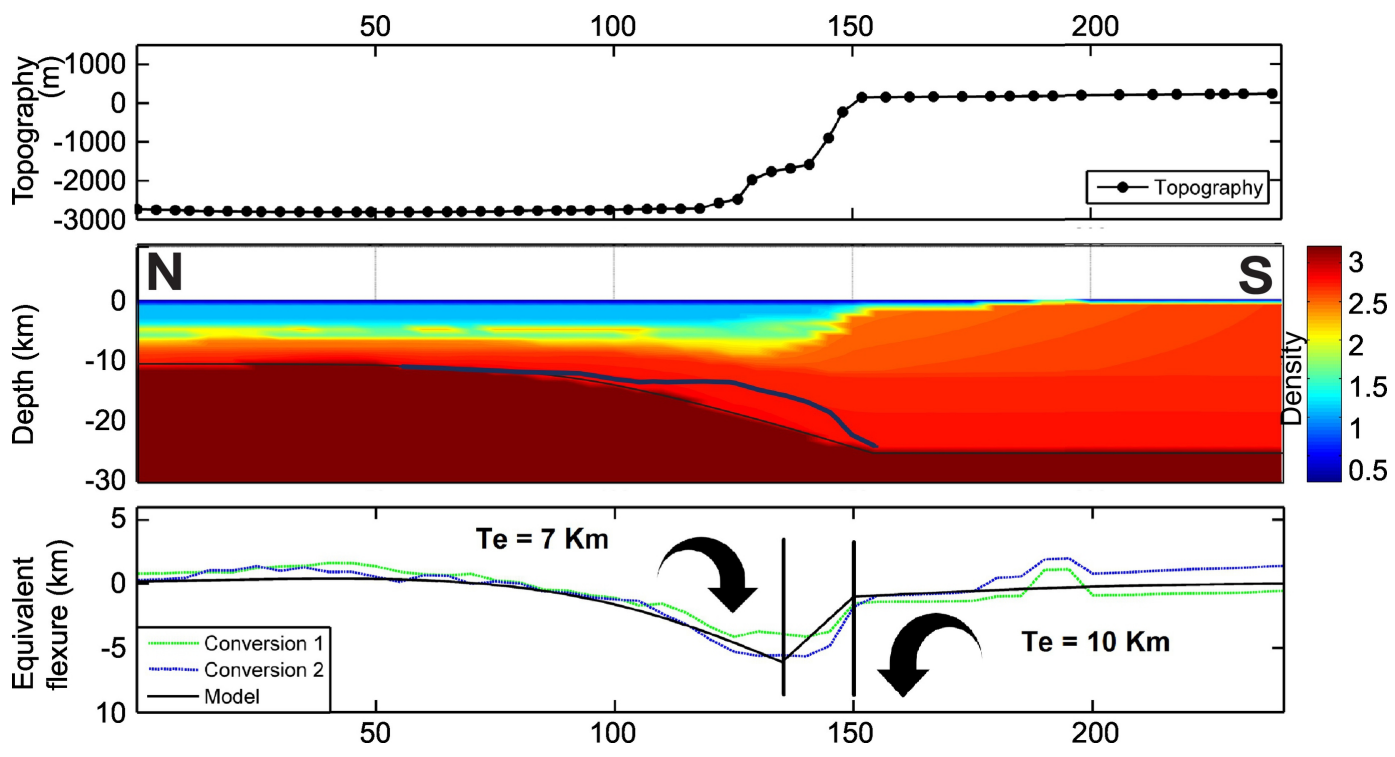

Figure 17 